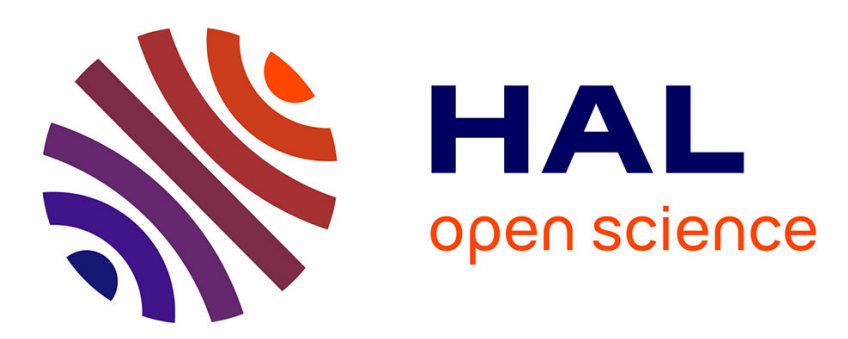

\title{
Evidence of sheared sills related to flank destabilization in a basaltic volcano
}

\author{
Carole Berthod, Vincent Famin, Jerôme Bascou, Laurent Michon, Benoit \\ Ildefonse, Patrick Monie
}

\section{- To cite this version:}

Carole Berthod, Vincent Famin, Jerôme Bascou, Laurent Michon, Benoit Ildefonse, et al.. Evidence of sheared sills related to flank destabilization in a basaltic volcano. Tectonophysics, 2016, 674, pp.195209. 10.1016/j.tecto.2016.02.017 . hal-01351758

\section{HAL Id: hal-01351758 \\ https://hal.univ-reunion.fr/hal-01351758}

Submitted on 21 Oct 2016

HAL is a multi-disciplinary open access archive for the deposit and dissemination of scientific research documents, whether they are published or not. The documents may come from teaching and research institutions in France or abroad, or from public or private research centers.
L'archive ouverte pluridisciplinaire HAL, est destinée au dépôt et à la diffusion de documents scientifiques de niveau recherche, publiés ou non, émanant des établissements d'enseignement et de recherche français ou étrangers, des laboratoires publics ou privés. 


\title{
Evidence of sheared sills related to flank destabilization in a basaltic volcano
}

\author{
C. Berthod ${ }^{\text {a,*, }}$, V. Famin ${ }^{\text {a }}$, J. Bascou ${ }^{\text {b }}$, L. Michon ${ }^{\text {a }}$, B. Ildefonse ${ }^{\text {c }}$, P. Monié ${ }^{c}$ \\ a Laboratoire GéoSciences, Université de La Réunion, Institut de Physique du Globe de Paris, UMR 7154, Sorbonne Paris Cité, CNRS, 97744 Saint Denis, France \\ b Université de Lyon, Université Jean Monnet, UMR CNRS IRD 6524, Laboratoire Magmas et Volcans, F-42023 Saint Etienne, France \\ c Geosciences Montpellier, CNRS UMR 5243, Université de Montpellier 2, Place Bataillon, 34095 Montpellier, cedex 5, France
}

\begin{abstract}
A B S T R A C T
Piton des Neiges basaltic volcano (La Réunion) has been deeply dissected by erosion, exposing large volumes of debris avalanche deposits. To shed light on the factors that led to volcano flank destabilizations, we studied the structure, the crystallographic and magnetic fabrics of the substratum of a debris avalanche unit. This substratum is a complex of $>50$ seaward-dipping sills that has been exposed by the avalanche. Structural observations show that the sill plane in contact with the avalanche is one of the latest intrusions in the sill complex. In this uppermost sill, the anisotropy of magnetic susceptibility (AMS) is correlated to the crystallographic preferred orientation of magmatic silicate minerals, allowing us to use AMS as a proxy to infer the magmatic flow. The AMS fabric across the intrusion is strongly asymmetric, which reveals that the contact sill was emplaced with a normal shear displacement of its hanging wall. The shear displacement and the magma flow in the intrusion are both directed toward the NNE, i.e. toward the sea, which is also the direction of the slope and of the debris avalanche runout. Because all the sills in the intrusion complex have a similar dip and dip direction, it is likely that several of them also underwent a cointrusive slip toward the NNE. We conclude that this cointrusive normal slip, repeated over many intrusions of the sill complex, increased the flank instability of the volcano. This incremental instability may have ended up into the observed debris avalanche deposit. At Piton de la Fournaise, the active volcano of La Réunion, sill intrusion and cointrusive flank displacement have been inferred from geophysical studies for the April 2007 eruption. By providing direct evidence of sheared sills, our study substantiates the idea that repeated sill intrusions may eventually trigger flank destabilizations in basaltic volcanoes.
\end{abstract}

\section{Introduction}

Destabilizations are rare but catastrophic processes of volcano flank failure, essentially known from their large-scale onshore and offshore deposits of debris avalanche breccia (Siebert, 1984; Moore et al., 1989; McGuire, 1996). The only observed example of such destabilization occurred during the eruption of Mount Saint Helens in May 1980 (Voight et al., 1981). Since then, coeruptive flank displacements have been documented at several volcanoes, like Kilauea in Hawaii (Montgomery-Brown et al., 2011), Mount Etna in Italy (Walter et al., 2005), and Piton de la Fournaise in La Réunion (Froger et al., 2015). Understanding how such displacements may evolve into destabilizations is important for volcanic risk management.

Coeruptive flank displacements may be driven by the combined effects of gravity and forceful magma injections (Swanson et al., 1976; Borgia, 1994; Lundgren, 2004). Forceful magma injection models assume that the volcano flank slides on a low-angle fault, pushed by the

\footnotetext{
* Corresponding author.

E-mail address: carole.berthod@univ-reunion.fr (C. Berthod).
}

recurrent injection of magma into vertical rift zones (Dieterich, 1988). This model is problematic because it requires a combination of an elevated magma overpressure and an extreme pressurization of pore fluids to explain the lateral push of the edifice flank (Iverson, 1995; Elsworth and Day, 1999). It has also been proposed that pressure variations in the magma reservoir could result in a lateral displacement of volcano flanks (Walter et al., 2005). Another cause of coeruptive flank deformation could be the lateral creep of a viscous zone at the base of the volcano, such as high-temperature olivine cumulates (Clague and Delinguer, 1994), yielding an extensional stress field above shallow reservoirs in the edifice that would favor eruptions.

Based on observations of a debris avalanche deposit at Piton des Neiges (the extinct and eroded volcano of La Réunion Island), Famin and Michon (2010) proposed an alternative model in which coeruptive lateral displacement is caused by repeated intrusions of sills in a detachment fault zone. Each sill would activate slip on the detachment, progressively increasing flank instability and eventually leading to flank failure. This model has been tested by numerical simulations, which show that sill intrusions in a volcanic edifice under extension may indeed yield lateral flank displacements, and may also activate a 
pre-existing detachment (Cayol et al., 2014; Chaput et al., 2014a). However, there is to date no observational constraints that sill intrusions cause a shear displacement during their emplacement.

The goal of this paper is to seek evidence of shear displacement during sill intrusions. To track such shear displacements, we studied the anisotropy of magnetic susceptibility (AMS) and the crystallographic fabrics of sill intrusions from the detachment and the "sill zone" (i.e. the stack of multiple sheeted sills) described by Famin and Michon (2010) and Chaput et al. (2014b). We combined this study with a structural reinvestigation of the sill zone in order to establish the chronology of deformation, intrusion, and destabilization events and to evaluate the structural impact of sills on the stability of a basaltic volcano, and thus their possible role in the initiation of flank failure.

\section{Geological setting}

La Réunion Island is composed of two volcanoes, Piton des Neiges, inactive and deeply incised by erosion, and Piton de la Fournaise, currently active and built on the southeastern flank of Piton des Neiges (Fig. 1). Our study focuses on Piton des Neiges, which occupies the northwestern two third of the island and culminates at an altitude of $3070 \mathrm{~m}$ above sea level. Piton des Neiges represents the most ancient preserved subaerial activity of La Réunion Island, as its oldest lavas have yielded $\mathrm{K}-\mathrm{Ar}$ ages up to $2.17 \pm 0.03 \mathrm{Ma}$ on the northern slop of the edifice Quidelleur et al. (2010), Fig. 1. From at least 2.17 Ma to $430 \mathrm{ka}$, Piton des Neiges underwent a stage of shield building, with an effusive eruptive style and the emission of mafic magmas. Then, after a 90 ka period of quiescence and erosion, the volcano entered into a post-shield stage at about $340 \mathrm{ka}$, with a more explosive activity and a production dominated by alkaline and differentiated magmas (Kluska, 1997). The end of Piton des Neiges activity has been dated at $29 \pm$ 3.0 ka by the K-Ar method (Gillot and Nativel, 1982) or $12.5 \pm 3.0$ ka by the U-Th method Deniel et al. (1992). In the course of its magmatic activity, Piton des Neiges has been affected by several destabilizations, as demonstrated by the presence of large volumes of debris avalanche breccias (Fig. 1). It is, however, unclear whether these large deposits are related to a small number of large and catastrophic avalanches or to multiple small destabilizations (Bachèlery et al., 2003; Bret et al., 2003; Oehler et al., 2004, 2007; Famin and Michon, 2010; Salvany et al., 2012).

The morphology of Piton des Neiges is characterized by three major depressions, the cirques of Cilaos, Mafate and Salazie. These depressions have been successively interpreted as scars of massive destabilizations (Bret et al., 2003; Oehler et al., 2004; Oehler et al., 2007), as the result of the subsidence of intrusive complexes after the end of volcanic activity (Gailler and Lénat, 2010), or as erosional structures (Salvany et al., 2012). Whatever the mechanism involved in their formation, the cirques have been preferentially incised by erosion, which enables the observation of the internal structure of the volcano. Taking advantage of this morphology, Famin and Michon (2010) reported the presence of a major detachment (i.e. a low-angle, outward-dipping normal fault) in the cirque of Salazie. The footwall of this detachment is a yet undated gabbroic intrusion interpreted as an extinct magmatic chamber of Piton des Neiges (Chevallier and Vatin-Perignon, 1982). The hanging wall of the detachment is an also undated breccia interpreted as a debris avalanche deposit (Famin and Michon, 2010). The mafic composition of breccia suggests that the debris avalanche is older than the post-shield stage of Piton des Neiges (i.e., older than $340 \mathrm{ka}$ ). The detachment itself is characterized by an intense ductile and brittle shear deformation toward the NE, localized within a 10-m-thick zone in the footwall. Sheared rocks are also heavily affected by hydrothermal alteration to greenschist facies. The gabbroic footwall is separated from the breccia hanging wall by a 50 -m-thick sill zone injected in the lithological discontinuity of the detachment (Chaput et al., 2014b). Sills are composed of olivine-rich basalt, which suggests that they occurred during the shield building stage of Piton des Neiges. Lenses of sheared and altered gabbro are pinched between the sills. Some sills in the sill zone are themselves heavily sheared, faulted, and altered, implying that

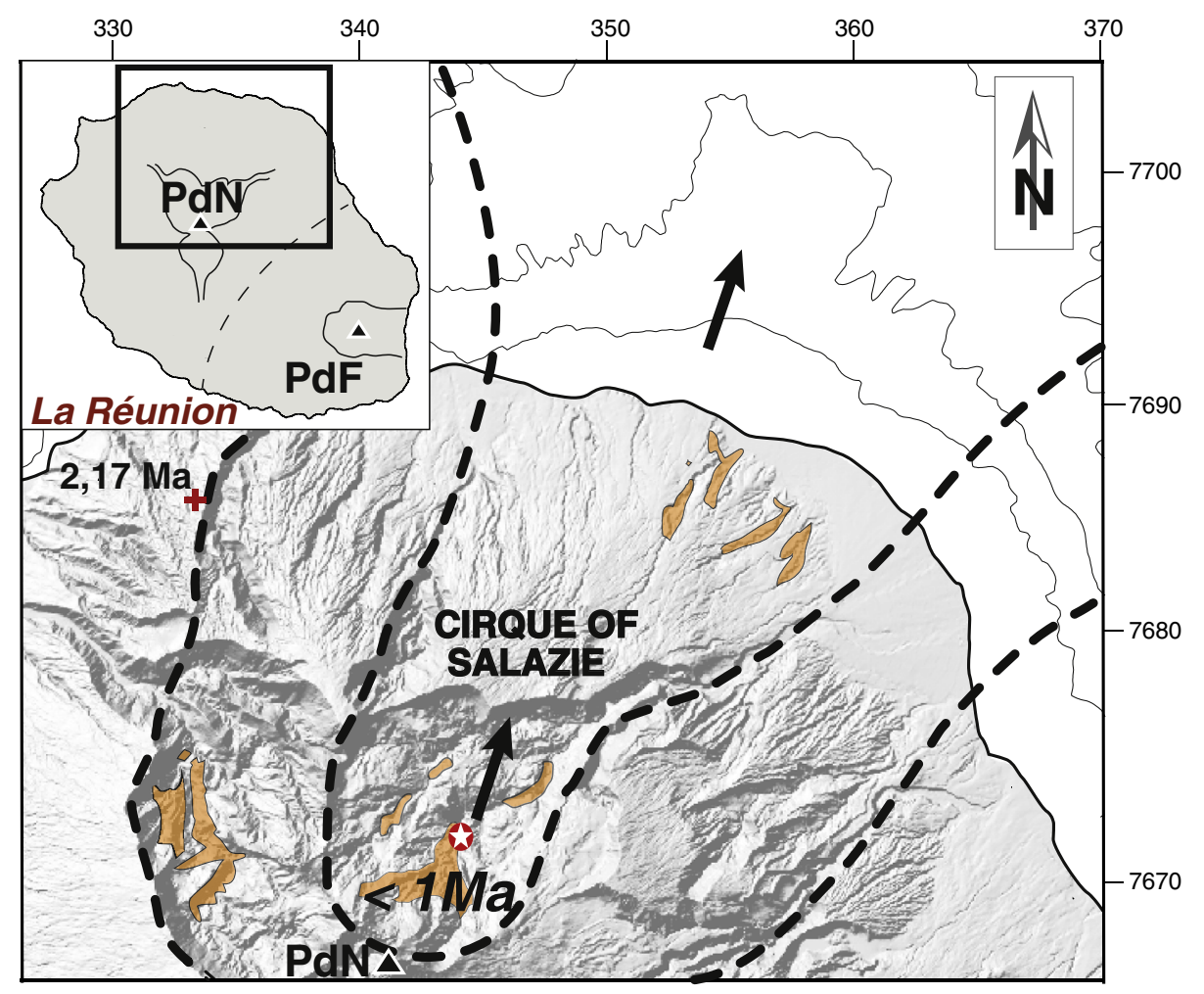

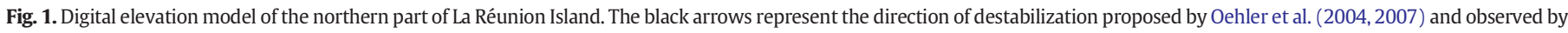

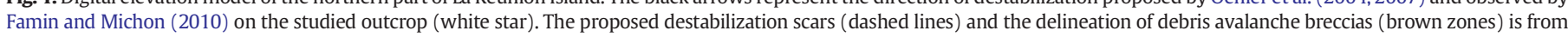
Bret et al. (2003) and Oehler et al. (2004, 2008). PdN stands for Piton des Neiges, PdF for Piton de la Fournaise. Coordinates in kilometers (UTM, WGS84). 
their injection occurred during the time span of detachment slip. From these observations, Famin and Michon (2010) proposed that sill intrusions repeatedly activated the detachment by two processes. The first process, a slow inter-intrusion creep due to the elevated temperatures carried by the intrusions, is recorded by ductile shear deformation.
The second process is a rapid cointrusive detachment slip due to the injection of pressurized magma in the slip plane. The purpose of this paper is to provide multi-scale structural evidence for this second process. The two processes could have greatly increased the instability of the volcano and might thus have led to debris avalanches.
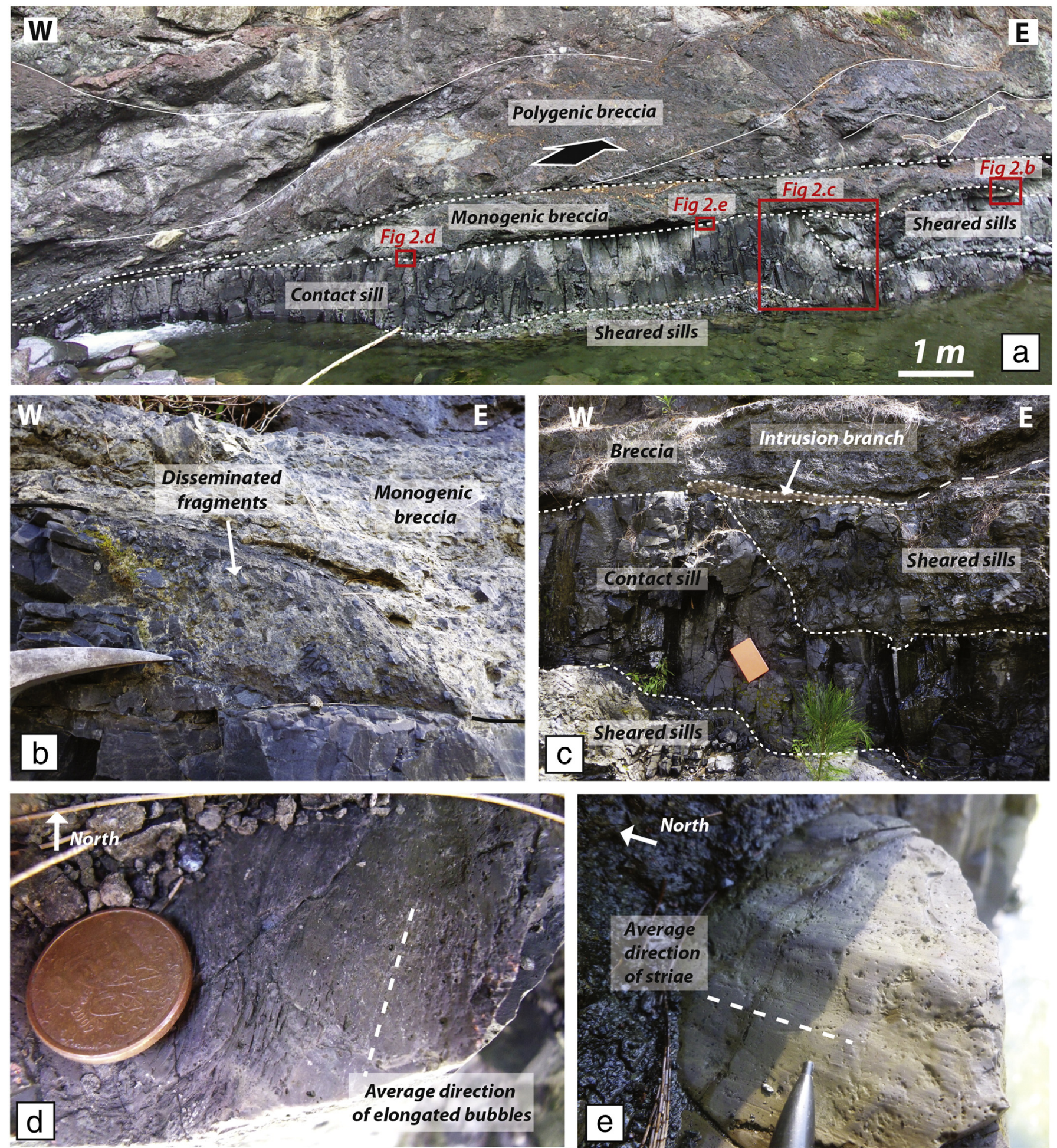

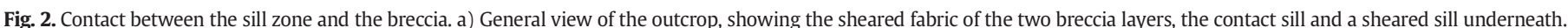

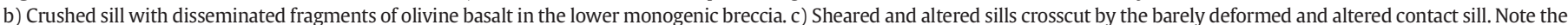

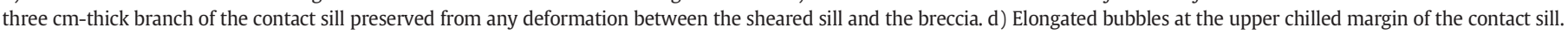
e) Striated upper surface of the contact sill chilled margin adjacent to the monogenic breccia. 


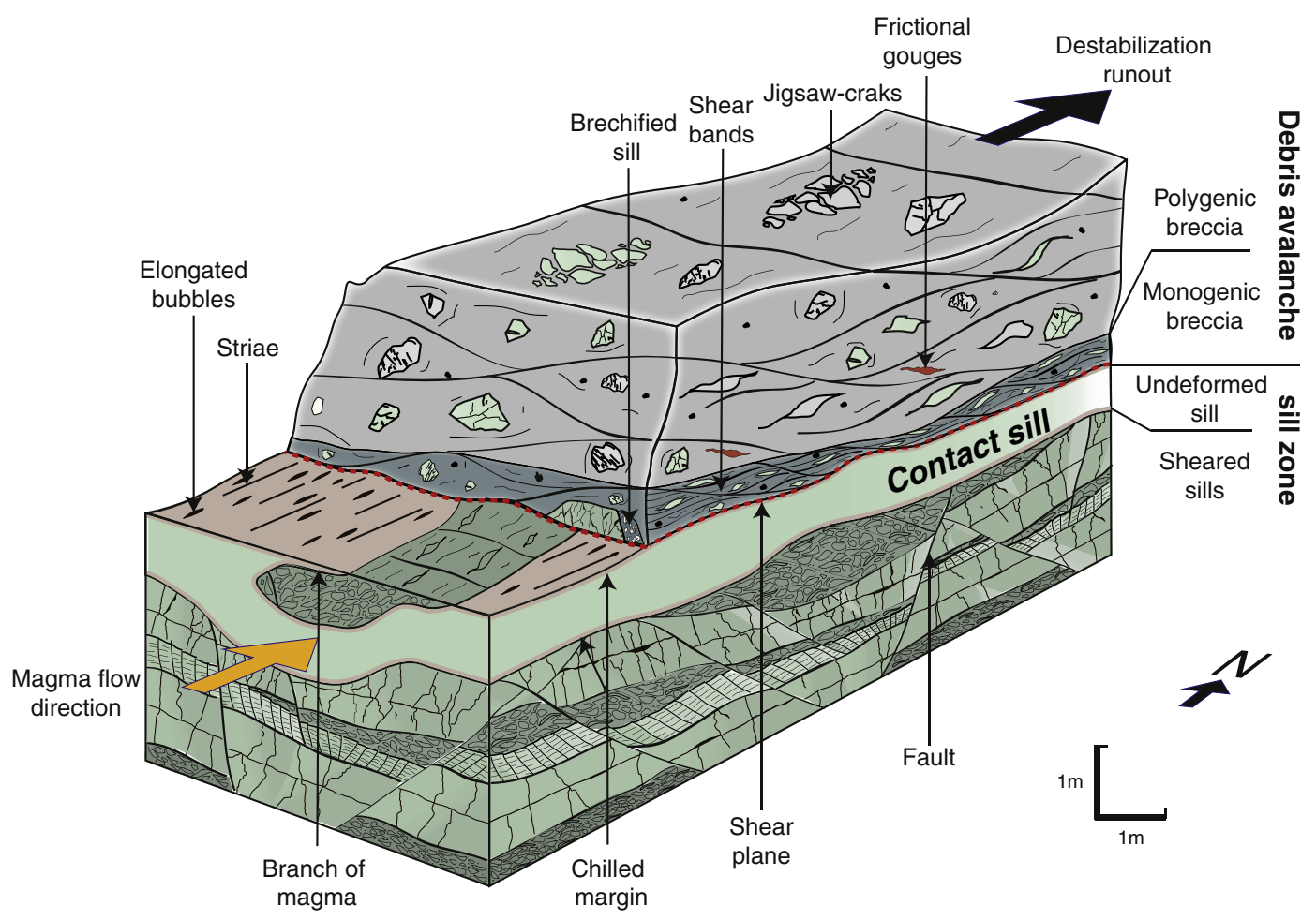

Fig. 3. Bloc diagram summarizing the structural features of the contact between the sill zone and the debris avalanche deposit.

\section{Structural study}

To understand the relationship between magma injections and the debris avalanche deposit, we focused our study on their interface, outcropping over about $50 \mathrm{~m}$ in the bed of the Mât River (Fig. 2). A diagram summarizing the observations made on this outcrop is shown in Fig. 3. The debris avalanche is composed of two breccia layers separated by a shear plane. The upper breccia layer, of which a $\sim 200 \mathrm{~m}$ thickness has been preserved, contains angular, polygenic fragments of basalt (Figs 2a, 3). The lower breccia layer, discontinuous (0 to $1 \mathrm{~m}$ thick) and in contact with the underlying sill zone, is heavily sheared and consists entirely of altered olivine-rich basalt clasts. Sills clasts are crushed and disseminated (Figs. 2a-b, 3), indicating that this lower breccia involved the top of the sill zone. In both the upper and lower breccias, jigsaw cracks in the clasts and frictional gouges indicate that the mechanism of deposition is a debris avalanche Famin and Michon (2010), Fig. 3. Sills have thus been emplaced between the gabbroic footwall and a hanging wall that is now missing, because the flank destabilization has removed it. The sill zone was therefore in reality thicker before the avalanche than it is today. The sill zone and the breccias are both cut by later few mafic intrusions, which are thus dykes since they intersect rock units (Fig. 3 ).

The contact between the sill zone and the breccias is made of a 90-cm- to 1-m-thick sill, hereafter called the "contact sill" (Figs. 2a, 3). The contact sill is barely altered and nearly undeformed, as evidenced by its intact chilled margins and by the preservation of delicate, $\mathrm{cm}$-thick intrusive branches stemming from the intrusion walls (Figs. 2c, 3). This intrusion crosscuts heavily altered and sheared
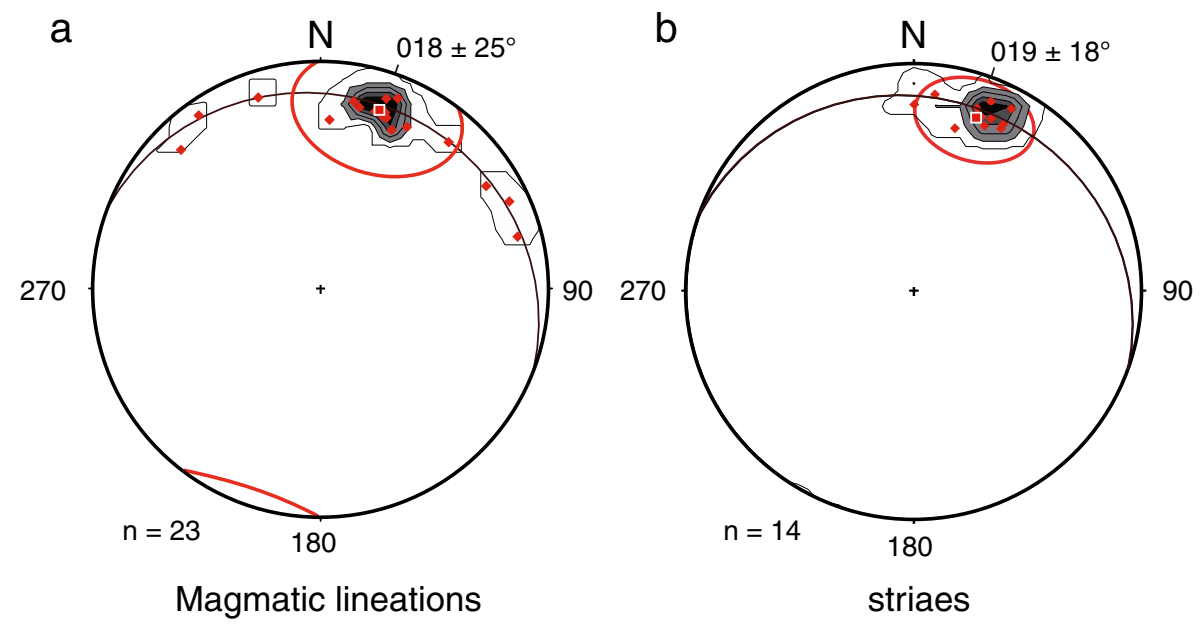

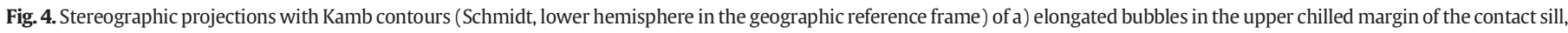

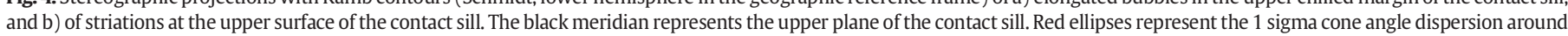
the averaged direction of data (red squares). 
sills and therefore postdates them (Figs. 2c, 3). Because the contact sill exhibits almost no deformation, it is necessarily one of the latest injections in the sill zone. On the upper chilled margin of the contact sill, the orientation of elongated bubbles indicates a N018 $\pm 25^{\circ} \mathrm{di}-$ rection of magmatic flow (Figs. 2d, 3, 4a). The upper chilled margin of the contact sill is a surface striated by the displacement of the overlying breccia (Figs. 2e, 3). The orientation of striae indicates a N019 $\pm 18^{\circ}$ average direction (Fig. 4b).

\section{Methods}

The anisotropy of magnetic susceptibility (AMS) is a widely used method to reveal the petrofabric of magma intrusions and lava flows, because it may provide valuable information on the flow dynamics (e.g. Cañón-Tapia, 2004; Hastie et al., 2011; Zhang et al., 2011; Boiron et al., 2013; Moreira et al., 2014; Hrouda et al., 2015). To better interpret the AMS and avoid difficulties related, for example, to the AMS-axes permutation producing inverse susceptibility fabrics due to the presence of single-domain magnetite grains, Bascou et al. (2005) and more recently Boiron et al. (2013) showed the importance of comparing the AMS with the shape and crystallographic preferred orientations (SPO and CPO). We applied the methodology developed by the authors across the 90-100 cm thickness of the contact sill. Samples were collected by two means. We first used a portable drill to retrieve cores of $25 \mathrm{~mm}$ in diameter and $22 \mathrm{~mm}$ long. We then obtained specimens in the missing intervals between cores by using a rotating disk saw to collect $2 \times 2 \mathrm{~cm}$ cubes. The total set of 88 samples over a sill thickness of $94 \mathrm{~cm}$ at the sample site includes 57 cores and 31 cubes. Each sample was oriented with a magnetic compass.

Polished thin sections were made from 15 samples and observed under optical microscope in transmitted and reflected light to determine the modal proportion (in vol.\%) of opaque phases across the sill. In order to specify the magnetic mineralogy contributing to the AMS, we investigated the variations of magnetic susceptibility vs temperature (K-T curves) on two samples. These two samples were powdered, heated at a rate of about $10{ }^{\circ} \mathrm{C} / \mathrm{min}$ up to 640 and $700{ }^{\circ} \mathrm{C}$, and then cooled to room temperature in an argon atmosphere. One of the two samples was also cooled to $-200{ }^{\circ} \mathrm{C}$ using liquid nitrogen and then heated back to room temperature. The susceptibilities versus low$\left(-200{ }^{\circ} \mathrm{C}\right.$ to $\left.20^{\circ} \mathrm{C}\right)$ and high-temperature $\left(20\right.$ to $\left.700{ }^{\circ} \mathrm{C}\right)$ curves were measured using the CS-L and CS-4 furnaces, respectively, coupled to a MFK1 Kappabrige instrument (AGICO Inc., Brno) at the University of Saint-Etienne (France). Thermomagnetic curves were processed using the Cureval 8.0 software (Chadima and Hrouda, 2009).

The AMS of cores and cubes was measured using the MKF1 Kappabridge and data were treated using the Anisoft 4.2 software (Chadima and Jelinek, 2008). The AMS mean tensor, calculated using the statistical method of Jelinek and Kropàcek (1978), is geometrically expressed as an ellipsoid with three principal axes $\left(K_{1}, K_{2}, K_{3}\right.$ with $K_{1} \geq K_{2} \geq K_{3}$ ). Data were corrected for the magnetic declination for La Réunion Island $\left(19.6^{\circ} \mathrm{W}\right)$.

The AMS ellipsoid provides the magnetic lineation, defined as the direction of the $K_{1}$ axis, and the magnetic foliation, defined by the plane containing the $K_{1}$ and $K_{2}$ axes and perpendicular to the $K_{3}$ axis. From $K_{1}, K_{2}, K_{3}$, the following parameters are computed: The bulk magnetic susceptibility $\mathrm{K}_{\mathrm{m}}=\left(\mathrm{K}_{1}+\mathrm{K}_{2}+\mathrm{K}_{3}\right) / 3$, the shape parameter $\mathrm{T}=2 \ln \left(\mathrm{K}_{2} / \mathrm{K}_{3}\right) / \ln \left(\mathrm{K}_{1} / \mathrm{K}_{2}\right)-1$, and the anisotropy degree $\mathrm{P}_{\mathrm{j}}=$ exp. $\left[\left[2\left(\ln K_{1} / K_{m}\right)^{2}+\left(\ln K_{2} / K_{m}\right)^{2}+\left(\ln K_{3} / K_{m}\right)^{2}\right]^{1 / 2}\right] . K_{m}$ is used as a proxy for the magnetic mineralogy of the sample and is correlated to the modal proportion of magnetic grains in the rock. The parameter $\mathrm{T}$ characterizes the shape of the AMS ellipsoid and varies from -1 (prolate magnetic fabric) to +1 (oblate magnetic fabric). $P_{\mathrm{j}}$ quantifies the degree of magnetic anisotropy and varies from 1 for an isotropic fabric to infinity.

The SPO of opaque phases was determined on four samples collected across the contact sill at 1, 4, 54 and $76 \mathrm{~cm}$ from the upper border. From each sample, two perpendicular thin sections were cut: the first in the $\left(\mathrm{K}_{1}-\mathrm{K}_{3}\right)$ plane and the second in the $\left(\mathrm{K}_{2}-\mathrm{K}_{3}\right)$ plane. On these six thin sections, photographs were taken in reflected mode and converted into binary images with black areas and white areas for the magnetic and non-magnetic minerals, respectively. These black-and-white images were then processed using the statistical software "Intercepts 2003", which determines the two-dimensional preferential distribution direction of mineral grains (Launeau et al., 1990; Launeau and Robin, 1996; Launeau et al., 2010).

We also compared the AMS and the SPO of opaque phases with the $\mathrm{CPO}$ of silicate minerals on the upper chilled margin of the contact sill. To do so, CPOs of olivine, clinopyroxene and plagioclase were determined on two samples at 1 and $4 \mathrm{~cm}$ from the upper margin by electron backscatter diffraction (EBSD) using a CamScan X500FE CrystalProbe scanning electron microscope (SEM) at Géosciences Montpellier (France). Samples were measured in automatic mode at a regular grid spacing of 1 or $3 \mu \mathrm{m}$ for analyses of microcrysts in the mesostasis, and at a grid spacing of $40 \mu \mathrm{m}$ for olivine macrocrysts. Generated diffraction patterns were processed using the Channel $5 \AA$ software suite (Schmidt and Olesen, 1989). A first stage of post-acquisition data processing was done using Channel $5 \circledR$ to increase the quality of the maps. Isolated pixels (either non-indexed, or indexed as a given phase and surrounded by pixels indexed for another phase) were removed, and non-indexed pixels that have a minimum of 5 neighbor pixels were filled with the same orientation. EBSD data sets were then processed using MTEX (version 4.0.23), a free Matlab toolbox for analyzing and modeling crystallographic data (http://mtex-toolbox.github.io; (Hielscher and Schaeben, 2008; Bachmann et al., 2010). We used MTEX to identify grains, to calculate pole figures of olivine, clinopyroxene, and plagioclase preferred orientations. Grains were identified by choosing a $10^{\circ}$ threshold, over which the misorientation between two adjacent pixels indexed for the same phase is assumed to be a grain boundary. Grains that have a surface smaller than 5 pixels could be erroneous measurements, and were removed from the data set. Twins in plagioclase were distinguished from grain boundaries by filtering out the $178^{\circ}$ to $180^{\circ}$ misorientations in the grain boundary identification. Pole figures were calculated using the average crystallographic orientation for each grain (i.e. one data point per grain, as in Boiron et al. (2013)). Results are presented on equal area, lower hemisphere projections in the specimen reference frame. In addition, we also used MTEX to characterize the CPO strength by calculating the J index of the orientation distribution function, which ranges from 1 in the case of random orientation to infinity in the case of an ideal single crystal (Mainprice et al., 2014).

\section{Results}

\subsection{Mineralogy}

The contact sill is composed of olivine-rich basalt, which consists of $0.2-2 \mathrm{~mm}$ olivine macrocrysts embedded in a microcrystalline groundmass (Fig. 5a-b). The size of microcrysts, including opaque phases, increases from $5-50 \mu \mathrm{m}$ at the sill margins to $30-300 \mu \mathrm{m}$ in the middle of the intrusion (Fig. $5 c-d$ ). Microcrysts in the groundmass include plagioclase, clinopyroxene, olivine, and opaque phases. Opaque phases consist of chromite and Fe-Ti oxides (magnetite and ilmenite intergrowths). Silicates and opaque phases are undeformed and most are also unaltered. The sequence of crystallization is olivine + chromite, Fe-Ti oxides, clinopyroxene, plagioclase (Fig. 5e-f). Throughout the sill, olivine macro- and microcrysts are slightly elongated (Fig. 5a-c). Clinopyroxene microcrysts are stocky with an aspect ratio (i.e. length/ width) close to 1 . Plagioclase microcrysts are tabular with an aspect ratio $>1$. Fe-Ti oxide microcrysts display either a cubic shape or a skeletal shape, with a variable aspect ratio. Skeletal Fe-Ti oxides are found as isolated dendrites elongated in one direction near the sill margins (Fig. 5e), whereas they display ripened dendrites with complex shapes toward the middle of the sill (Fig. 5f). The modal proportion of 

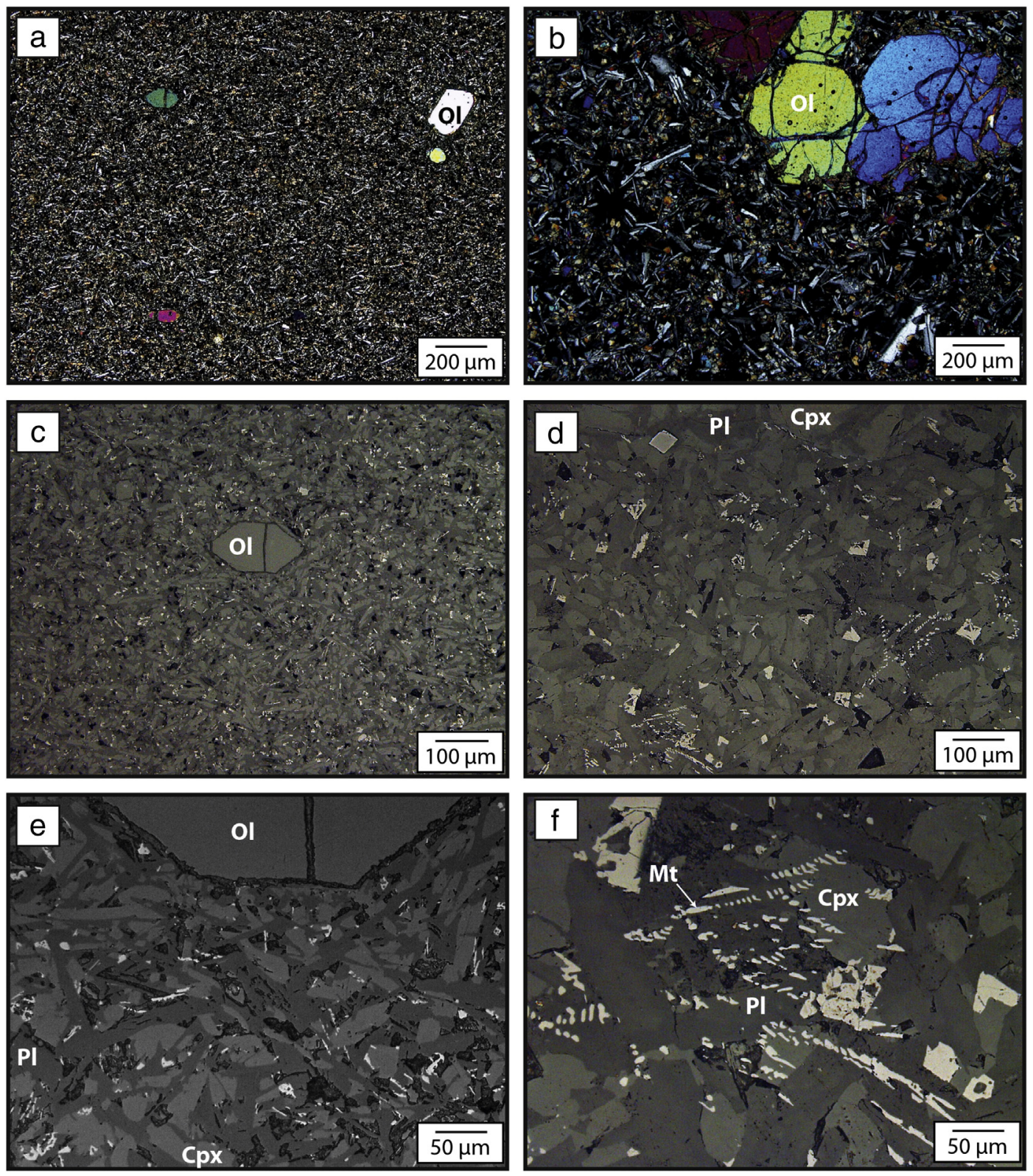

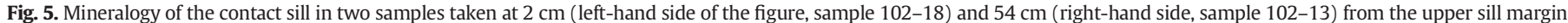

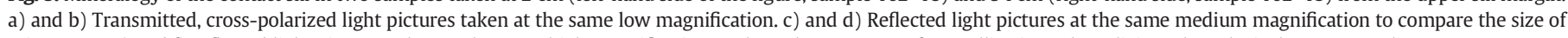

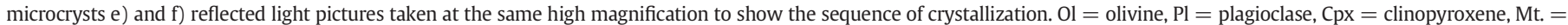
titanomagnetite.

opaque phases increases from less than $1 \%$ at the sill margins to more than $4 \%$ in the middle of the sill (Fig. 6 ).

The magnetic susceptibility vs temperature curves established on two samples are presented in Fig. 7. The heating curve, starting from $-200{ }^{\circ} \mathrm{C}$, yields two peaks of magnetic susceptibility. The first one at $-185^{\circ} \mathrm{C}$ confirms the presence of chromite among the opaque phases (Clark, 1997). The second peak, at $500-505{ }^{\circ} \mathrm{C}$, corresponds to the Curie temperature of titanomagnetite having a low Ti content, with an average composition of $\mathrm{Fe}_{2.87-2.88} \mathrm{Ti}_{0.13-0.12} \mathrm{O}_{4}$, (Clark, 1997). The nonreproducibility of the cooling curve indicates mineralogical transformations probably caused by oxidation of low-Ti magnetite during the heating process.

\subsection{Anisotropy of magnetic susceptibility}

The anisotropy of magnetic susceptibility displays variations in orientation and magnitude across the contact sill. AMS data are provided in Table 1 and represented in Figs. 8 and 9. In a stereographic projection, the $\mathrm{K}_{1}$ and $\mathrm{K}_{2}$ axes are scattered in the intrusion plane and do not define a clear magnetic lineation (Fig. 8a). In contrast, the $K_{3}$ axes of individual samples display a relatively well-defined cluster with maximum centered on the pole of the contact sill and a trend in the SW-NE direction (Fig. 8a). It is also important to note that the majority of $\mathrm{K}_{3}$ axes dip toward the South in the geographic reference frame (Fig. 8a), but toward the North relative to the intrusion plane (Fig. 8b), which indicates a predominant South dip of the magnetic foliations relative to the sill. In a transect view across the contact sill, the mean susceptibility $K_{m}$ ranges from 0.012 SI to 0.04 SI (Fig. 9a), which indicates a dominant contribution of ferromagnetic grains to the AMS. The $\mathrm{K}_{\mathrm{m}}$ values are minimum at the upper margin of the contact sill and increase from both the upper and lower margins toward the center. This $\mathrm{K}_{\mathrm{m}}$ distribution yields an asymmetric parabolic profile across the intrusion. In a projection view of magnetic foliations onto a N018 axis (the averaged direction of bubble elongations, Fig. 4a), it 
also appears that the magnetic foliations of individual samples are organized into three zones across the sill (Fig. 9b): North-dipping magnetic foliations at $0-5 \mathrm{~cm}$ from the upper chilled margin, subvertical South-dipping foliations at 5-30 cm, and moderately dipping foliations at 30-94 cm with a majority toward the South. The shape parameter T ranges from -0.894 to +0.928 across the contact sill (Fig. 9c), with a majority of positive values and an average at +0.22 . This indicates a planolinear to oblate AMS ellipsoid $(0<\mathrm{T}<1)$, which confirms the dominantly planar magnetic fabric. The degree of magnetic anisotropy $P_{j}$ is weak, ranging from 1.004 to 1.052 (Fig. 9d) with an average at 1.014 typical of basaltic rocks (Tauxe et al., 1998; Callot et al., 2001). $P_{j}$ values are organized into three zones across the contact sill: scattered values of 1.005 to 1.033 between 0 and $30 \mathrm{~cm}$ from the upper margin, a peak reaching 1.052 between 30 and $60 \mathrm{~cm}$, and a slow increase from 1.004 at $60 \mathrm{~cm}$ to 1.021 at $94 \mathrm{~cm}$ on the lower margin.

\subsection{Shape and crystallographic fabrics}

Opaque and silicate phases both display an organized pattern in the contact sill. The SPO of opaque phases deduced from the analysis of thin section photographs is shown in Fig. 10. In the upper sample located at $1 \mathrm{~cm}$ from the upper sill margin, the SPO ellipse of opaque phases has a short axis at $1^{\circ}$ from the $K_{3}$ axis in the $\left(K_{1}-K_{3}\right)$ plane and at $6^{\circ}$ from $K_{3}$ in the $\left(\mathrm{K}_{2}-\mathrm{K}_{3}\right)$ plane (Fig. 10a). At $4 \mathrm{~cm}$ from the upper sill margin, the short axis of the opaque SPO ellipse is at $5^{\circ}$ from $K_{3}$ in the $\left(K_{1}-K_{3}\right)$ plane, and at $7^{\circ}$ from $K_{3}$ in the $\left(K_{2}-K_{3}\right)$ plane (Fig. 10b). In the middle sample ( $54 \mathrm{~cm}$ from the upper sill margin), the short axis of the opaque SPO ellipse is at $24^{\circ}$ from $K_{3}$ in the $\left(K_{1}-K_{3}\right)$ plane, and at $24^{\circ}$ from $K_{3}$ in the $\left(K_{2}-K_{3}\right)$ plane (Fig. 10c). In the lower sample $(76 \mathrm{~cm}$ from the upper sill margin), the short axis of the opaque SPO ellipse is at $0.1^{\circ}$ from $K_{3}$ in the $\left(K_{1}-K_{3}\right)$ plane and at $3.4^{\circ}$ from $K_{3}$ in the $\left(K_{2}-K_{3}\right)$ plane (Fig. $\left.10 \mathrm{~d}\right)$. Hence, the angle between the magnetic fabric and the distribution fabric of opaque phases is within an angle of $7^{\circ}$ near the sill margins, and $24^{\circ}$ in the middle of the sill.

EBSD measurements of silicate CPOs at 1 and $4 \mathrm{~cm}$ from the upper margin are shown in Fig. 11. Olivine displays the highest fabric strength with a J index at 1.77-1.83 and a highest maximum density on [010]. Clinopyroxene strength fabric is the smallest with a J index at 1.181.30. Plagioclase displays intermediate $\mathrm{J}$ indexes of $1.55-1.61$ and a highest maximum density on (010). There is a good consistency among the crystallographic fabrics of silicate minerals: (010) plagioclase, [010] olivine and (010) clinopyroxene tend to be parallel to

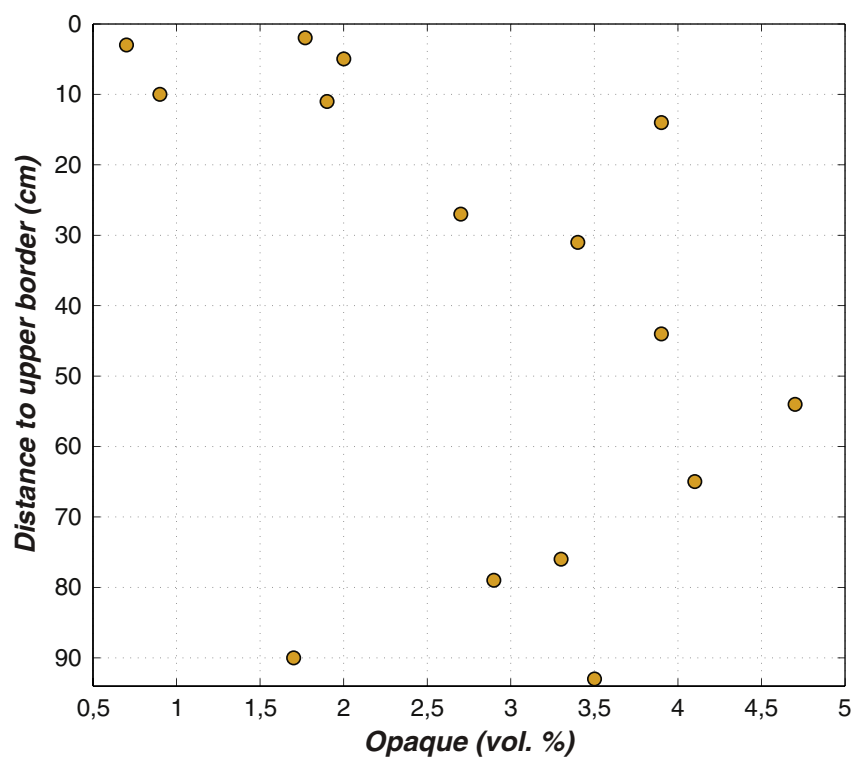

Fig. 6. Distribution of the modal proportion of opaque phases across the contact sill. each other. [100] plagioclase, [001] clinopyroxene and [001] olivine also tend to be parallel. Finally, (001) plagioclase tends to be parallel to (100) clinopyroxene. The CPO of silicates is thus of the type "axialB" (Satsukawa et al., 2013), which means that the fabric is dominantly planar. It is also important to note that the values of the J index are small, and thus that the fabrics of silicate minerals are weak.

\section{Discussion}

\subsection{Comparison of AMS and crystallographic fabrics}

To interpret the magnetic fabric of the contact sill, it is important to determine how the AMS is related to the flow-induced mineral fabric. In most rocks, the AMS is mainly due to the anisotropic shape of grains or shape anisotropy, and/or to the crystallographic anisotropy of the grains or magnetocrystalline anisotropy (Graham, 1954; Stacey, 1960; Ellwood, 1978; Rochette et al., 1992). In mafic volcanic rocks such as basalt, titanomagnetite is generally the main contributor to the magnetic fabric. Because this mineral has a cubic crystal structure, the magnetocrystalline anisotropy is very weak and the observed anisotropy essentially results from the shape anisotropy of titanomagnetite grains due to a heterogeneous development of dendrites at the cube summits, and from the anisotropic distribution of these grains between the silicate phases (Hargraves et al., 1991).
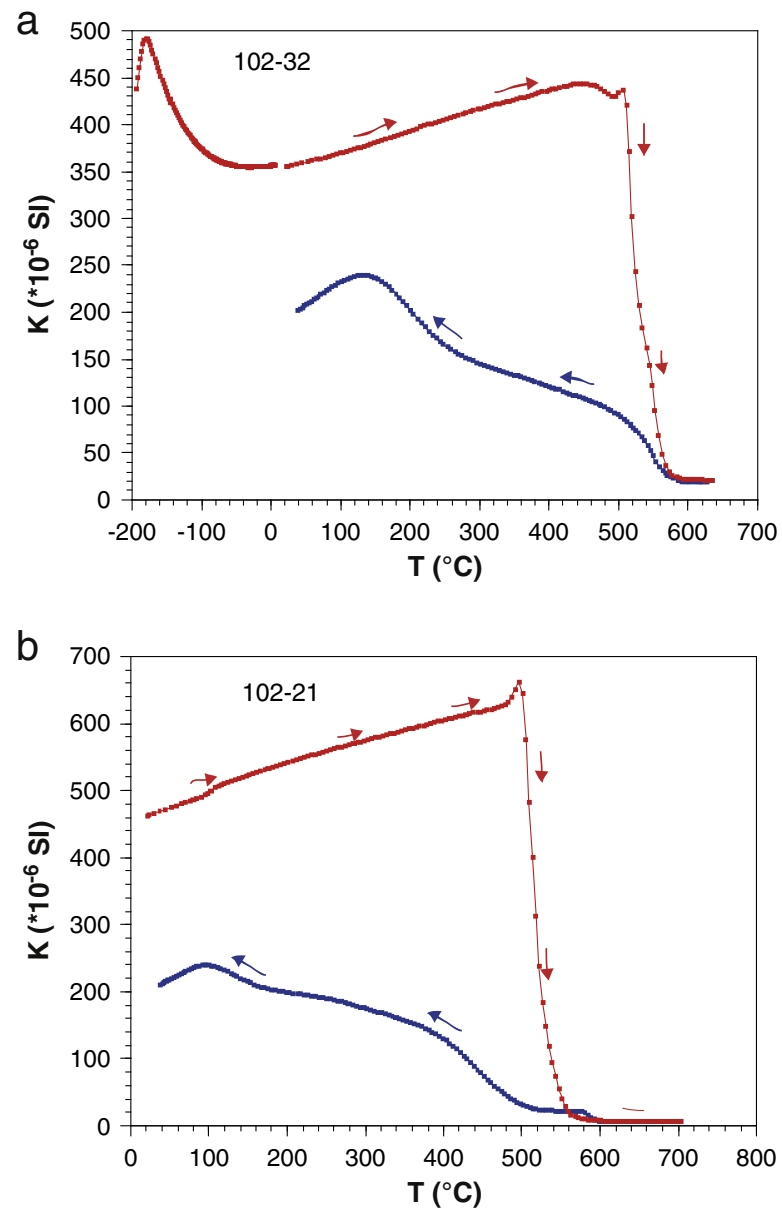

Fig. 7. Thermomagnetic determination of magnetic susceptibility $(\mathrm{K})$ versus temperature (T) for two samples taken a) at $26 \mathrm{~cm}$ from the upper sill margin (sample 102-32), and b) $57 \mathrm{~cm}$ from the upper sill margin (sample 102-21) obtained in argon atmosphere. The red curve represents the heating path; the blue curve represents the cooling path. (For interpretation of the references to color in this figure legend, the reader is referred to the web version of this article.) 


\begin{tabular}{|c|c|c|c|c|c|c|c|c|c|c|c|c|c|c|c|c|c|c|c|c|c|c|c|c|c|c|c|c|c|}
\hline 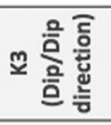 & 量施 & 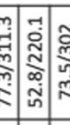 & مُ & & & & & & & & & & & & & & & & & & & & & & & & 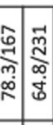 & & : \\
\hline 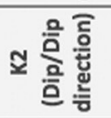 & 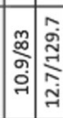 & 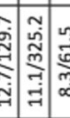 & 管 & $\stackrel{\infty}{\infty}$ & & & & & & & & & & & & & & & & & & : & & & & & 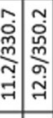 & & 雚 \\
\hline 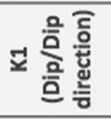 & 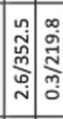 & 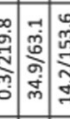 & & $\mid \begin{array}{l}\tilde{m} \\
\dot{p} \\
\infty \\
\infty\end{array}$ & & & & & & & & & & & & & & & $\underset{\mathbb{N}}{\sim}$ & & & & & & $\vec{m}$ & & & & \\
\hline 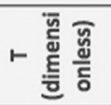 & $\begin{array}{lll}0 & \infty \\
0 \\
0 \\
0\end{array}$ & 央 & & & & & & & & & & & & & & & & & & & & & & & ma & & 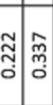 & & \\
\hline 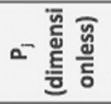 & 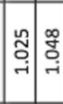 & & & & & & & & & & & & & & ț & & & & & & & & & & 월 & & 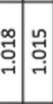 & & \\
\hline 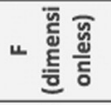 & 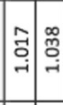 & & & & & & & & & & & & & t. & 7 & & & & & & & & & & & & పేర్య & & \\
\hline 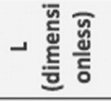 & 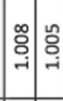 & & & & & & & & & & & & if & -1 & i & & & & & & & & & & ๘ & & & & \\
\hline 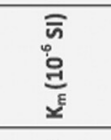 & 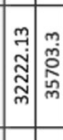 & 卢 & ?. & 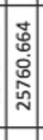 & 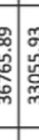 & | & 范 & & & 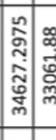 & & & 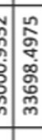 & 望 & 离 & ले & & 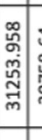 & 宫递 & & 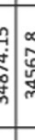 & 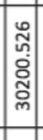 & & & 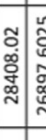 & & 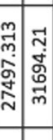 & & 年 \\
\hline$\stackrel{0}{2}$ & 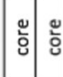 & & & & & & ัํํ & & 气ั & : & & & 巳 & 坣 & ${ }^{\circ}$ & & & 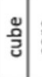 & & & 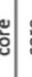 & 8 & & 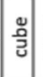 & & & 气ั & & \\
\hline 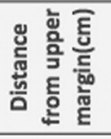 & 的 & & & & & & & & & & & & ت & & & & & & | & & & $\varpi_{\infty}$ & & & 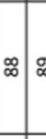 & & 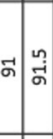 & & \\
\hline 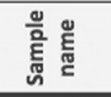 & 总 & & & & & & & & & 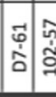 & P & & & 8 & ปี่ & & & & 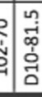 & & 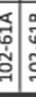 & & & & 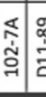 & ప્ન & تُّ & & 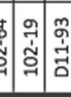 \\
\hline 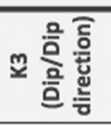 & 离 & $\begin{array}{l}\infty \\
\infty\end{array}$ & $\begin{array}{lll}0 \\
\end{array}$ & & & 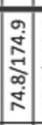 & 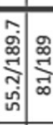 & & & & ${ }^{\circ}$ & $\stackrel{\infty}{\infty}$ & & & & $\approx$ & & : & 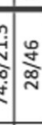 & & id & & & 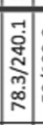 & స్. & $m$ & 象鹰 & & \\
\hline 里容 & ज्ञेल & 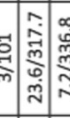 & 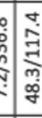 & & 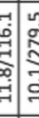 & $\mid$ & 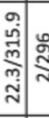 & & & 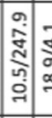 & 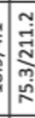 & & â & 商: & & ฮู่ & & ปี่ & 4 & & 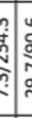 & & & & 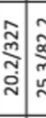 & & & & F \\
\hline 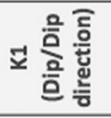 & 部 & 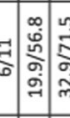 & & & & 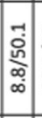 & 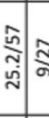 & & & & $\stackrel{m}{m}$ & iี & ڤి & & & $\gamma$ & & 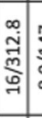 & ถุ่ & & & 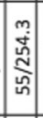 & & & 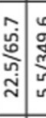 & & & & \\
\hline ト & 咅 & & & & & 管 & & & & $\vec{b}$ & 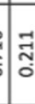 & & $=$ & 苛 & & & & 1 & & & & ల్ & 离 & 惫 & 趈 & 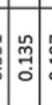 & ఫ̊ & & $\begin{array}{l}n \\
\text { s. }\end{array}$ \\
\hline 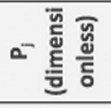 & 㑒 & & & & & 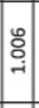 & . & & & : & & & 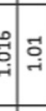 & -1 & 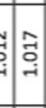 & & & 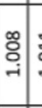 & 7 & & & 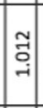 & & : & $\stackrel{n}{ت}$ & 7 & 承 & & : \\
\hline 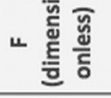 & 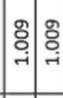 & & & & & | & & & 1 & 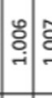 & & & 1 & $i$ & 4 & & & 8 & & & & 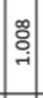 & & : & i & 7 & & & \\
\hline 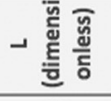 & ${ }^{-1}$ & & & & & ఫ్థా & ğ & & 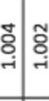 & $\overrightarrow{0}: \vec{्}$ & & & i & . & 1 & & & ఫ్ & $\stackrel{0}{0}$ & & & ? & 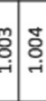 & $\mid$ & ఫ̊ં & ఫ్తి & | & & -7 \\
\hline 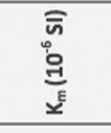 & 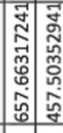 & 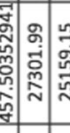 & 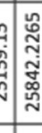 & 战 & & 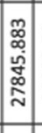 & : & & & 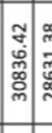 & & & & ले & & & & 娄 & $\infty$ & & 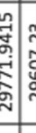 & | & 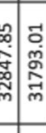 & m & 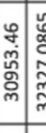 & $m$ & $g$ & & 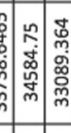 \\
\hline$\stackrel{2}{2}$ & בُ & (2) & & & & 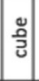 & & & పั) & ؛े & & & ¿ & 8 & ఏ & & & $\stackrel{0}{5}$. & & & & ${ }^{\circ}$ & 8 & 라 & ธั้ & 5 & 010 & & 罗 \\
\hline 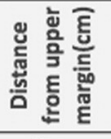 & & & & & & & & & & & & & & & & & & & & & & & & & & & $\vec{m}$ & & $|\stackrel{\mathscr{m}}{\mid}|$ \\
\hline 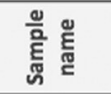 & 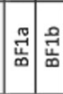 & 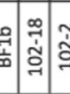 & & & & & & & ఫొ & & & & & & & & & & & & & & & 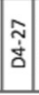 & & 齐 & & & 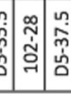 \\
\hline
\end{tabular}


Several lines of evidence support the validity of this interpretation for the contact sill. First, the general increase of the mean magnetic susceptibility $K_{m}$ (Fig. 9a) matches the increased modal proportion of opaque phases toward the middle of the sill (Fig. 6), which indeed suggests that the magnetic susceptibility is correlated to the abundance of opaque phases. Second, titanomagnetite is the main contributor to the magnetic signal among opaque phases (Fig. 7), which implies that the magnetocrystalline anisotropy has only a small contribution to the AMS in the intrusion. Third, there is a general consistency between the magnetic fabric and the anisotropic distribution of opaque phases (Fig. 10): the short axis of the opaque SPO ellipse is within $7^{\circ}$ from the $\mathrm{K}_{3}$ orientation near the sill margins (samples at 1,4 and $76 \mathrm{~cm}$ ), and $\leq 24^{\circ}$ of $K_{3}$ in the middle of the sill (sample at $54 \mathrm{~cm}$ ). The agreement between the AMS and the distribution of opaque phases is probably better near the sill margins because of the simple shape of isolated and elongated $\mathrm{Fe}-\mathrm{Ti}$ oxide dendrites, compared to the more complex shape of ripened dendrites in the middle of the intrusion (Fig. 5e-f). The consistencies between $\mathrm{K}_{\mathrm{m}}$ and the abundance of opaque phases, and between the AMS and the anisotropic distribution of opaque phases, suggest that the magnetic fabric is governed by the shape and distribution of opaque phases, among which titanomagnetite is the main magnetic contributor.

The crystallographic fabric of silicates also matches the magnetic fabric and the distribution fabric of opaque phases, as shown in Fig. 12. At $1 \mathrm{~cm}$ from the upper sill margin, the AMS $K_{3}$ axis, the short axis of the opaque SPO ellipse, and the eigenvectors E1 of [010] olivine, (010) pyroxene, and (010) plagioclase are clustered within a cone angle of $16.3^{\circ}$. At $4 \mathrm{~cm}$ from the upper sill margin, $K_{3}$, the short axis of the opaque SPO ellipse, and the eigenvectors E1 of [010] olivine, (010) pyroxene, and (010) plagioclase are clustered within a cone angle of $15.9^{\circ}$. In both samples, $K_{1}$ is also in reasonable agreement with [100] plagioclase, suggesting a match between the magnetic and crystallographic lineations at the sill margins. Furthermore, the magnetic fabric and the crystallographic fabric of silicates are both planar according to the parameter $\mathrm{T}$ and to the highest maximum densities found on [010] olivine and (010) plagioclase in these two samples. These lines of evidence indicate that the AMS and the distribution of opaque phases are not only consistent with each other, but are also consistent with the crystallographic fabric of silicates. The magnetic fabric is thus considered as representative of the minerals fabric.

\subsection{The use of mineral and AMS fabrics to infer magmatic flow}

The kinematics of magmatic flow in an intrusion may be partly reconstructed from the fabric of minerals. Within a laminar flow of magma through an intrusion, crystals act as rigid particles and undergo some rotations due to the mechanical drag between the magma and the solid walls. Even at low concentrations of crystals, these rigid particles interact with each other, and eventually become aligned with their long axis at an acute angle to the flow direction (Ildefonse et al., 1992; Arbaret et al., 1996; Ildefonse et al., 1997). This spatial arrangement induces a tiling pattern, especially for the particles having a planar shape, which results in an imbrication angle of the particles relative to the intrusion margins.

The sign of the imbrication angle may be used to infer the sense of shear of the magma relative to the intrusion walls. In a planar intrusion without along-plane displacement of the walls, the imbrications on the two margins should be symmetric relative to the intrusion axis, resulting in a symmetrical fabric (Knight and Walker, 1988). In the case of along-plane displacement of one of the margins, the imbrications and hence the fabric become asymmetric. The degree of asymmetry depends on the relative orientations and magnitudes of the flow velocity and wall displacement velocity vectors (CorreaGomes et al., 2001).

Because Fe-Ti oxides (including titanomagnetite) crystallize after olivine and before clinopyroxene and plagioclase (Fig. 5), it is reasonable to assume that the magnetic minerals acted as rigid particles arranged by magmatic flow. Given the above-mentioned consistency between the mineral fabrics and the magnetic fabric, the AMS can be used to reconstruct the shear sense between the flowing magma and the sill walls, and thus the kinematics of sill emplacement.

To determine the orientation of the flow vector in dykes by the AMS, Knight and Walker (1988) proposed to use the imbrication angle of the $\mathrm{K}_{1}$ axis (the magnetic lineation) relative to each margin. However, in some circumstances, especially in the case of oblate fabrics, $\mathrm{K}_{2}$ may also be aligned at low angle to the flow vector, resulting in a large dispersion of $\mathrm{K}_{1}$ axes (Khan, 1962; Ellwood, 1978; Knight and Walker, 1988; Dragoni et al., 1997; Philpotts and Philpotts, 2007). To circumvent this issue, another method is to use instead the imbrication angle of the magnetic foliation to infer the magma flow direction and sense relative to each margin (Geoffroy et al., 2002; Geoffroy et al., 2007). This imbrication angle is also the angle between $\mathrm{K}_{3}$ (the pole of the magnetic foliation) and the pole of the intrusion plane. In the contact sill studied in this paper, the dispersion of $\mathrm{K}_{1}$ axes is greater than the dispersion of $\mathrm{K}_{3}$ axes (Fig. 8a). Moreover, the AMS parameter T displays dominantly oblate fabrics (Fig. 9c). Therefore, we take $\mathrm{K}_{3}$ as a more reliable indicator of magma flow than $K_{1}$ and determine the imbrication $\left(I_{p}\right)$ from the angle between $\mathrm{K}_{3}$ and the pole of the sill plane.

Ildefonse et al. (1997) and Arbaret et al. (2000) showed that, in general, the value of $\mathrm{I}_{\mathrm{p}}$ is not correlated to the shape of the strain ellipsoid, except in the case of crystal interactions and small deformation (i.e. limited magmatic flow). This later case corresponds to an imbrication between $45^{\circ}$ and the direction of flow. In the contact sill, magnetic mineral grains are microcrysts (as opposed to olivine macrocrysts, Fig. 5) that crystallized at sub-solidus conditions, probably just before the arrest of magma flow in the sill. Therefore, it is possible that the magnetic minerals, and moreover clinopyroxene and plagioclase, only crystallized during the last increment of magmatic flow and recorded only a weak deformation. This interpretation is supported by the weak SPO of opaque phases (Fig. 10), by the low CPO strength of silicate minerals in general, and by the lower CPO strengths of clinopyroxene and plagioclase compared to olivine in particular (Fig. 11). In addition, the SPO of individual and clustered magnetic grains, represented by the degree of anisotropy $\left(\mathrm{P}_{\mathrm{j}}\right)$, should be proportional to the intensity of shear during this last increment of flow. Such relationship was documented by analogue flow modeling (Cañón-Tapia and Pinkerton, 2000; Akkoyun et al., 2013). Consequently, we hereafter consider the possibility that the values of $I_{p}$ and $P_{j}$ might be connected to the shape of the strain ellipsoid, keeping in mind that this interpretation is only valid if the magnetic minerals crystallized during the last step of flow in the sill as the magma reached its solidus.

\subsection{Kinematics of sill emplacement}

According to the above discussion, we make use of the AMS data to determine the direction and sense of magma flow in the contact sill. The profiles of AMS parameters across the sill show that the magnetic fabric is not chaotic in the intrusion. The orientation of $\mathrm{K}_{3}$ axes and the positive shape parameter T suggest that the magmatic fabric is planar and at low angle to the intrusion walls (Figs. 8, 9c), and thus that the magmatic flow was essentially laminar. The parabolic increase of the bulk susceptibility magnitude $\mathrm{K}_{\mathrm{m}}$, devoid of abrupt variations (Figs. 9a, 13a), also suggests that the intrusion was emplaced as a single magma injection. The SW-NE scatter of $\mathrm{K}_{3}$ axes (Fig. 8a) is consistent with the N018 $\pm 25^{\circ}$ orientation of elongated bubbles (Fig. 4a) in defining a SSW-NNE direction of magmatic flow in the contact sill. The North-dipping magnetic foliations in the 5 - $\mathrm{cm}$-thick zone from the upper margin indicate a top-to-the-South simple shear relative to the upper wall. In contrast, the predominance of South-dipping magnetic foliations at $5-94 \mathrm{~cm}$ records a top-to-the-North simple shear relative to the lower wall (Figs. 9b, 13b). The opposite shear senses at the two sill margins 

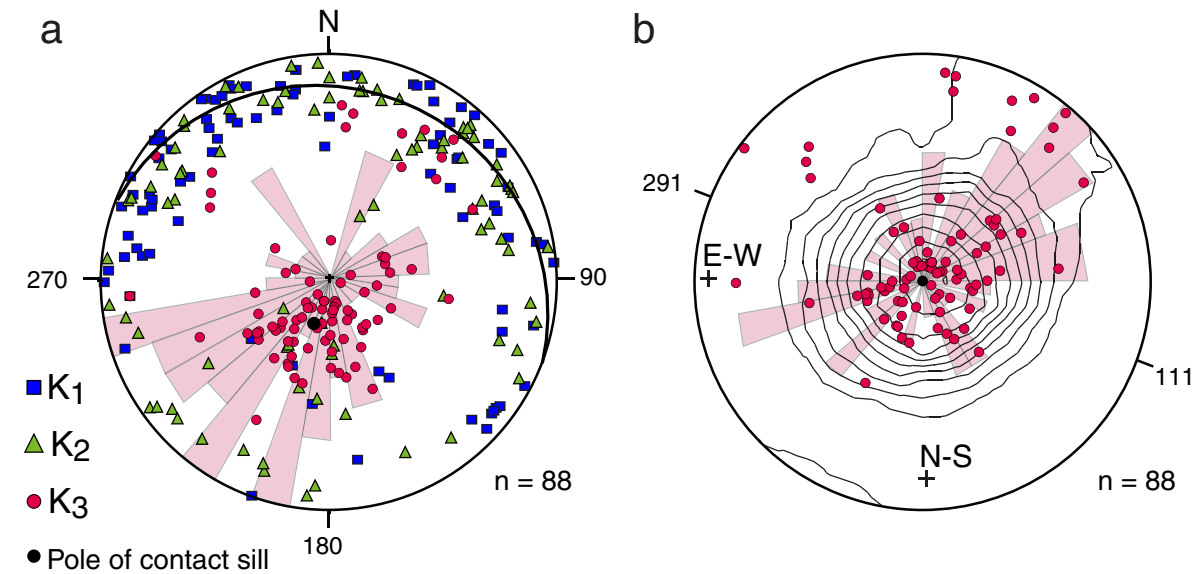

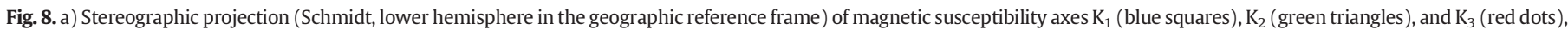

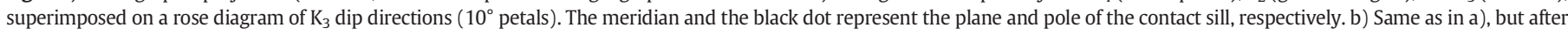

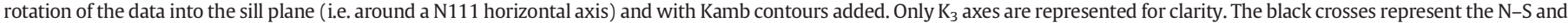
E-W axes after rotation. (For interpretation of the references to color in this figure legend, the reader is referred to the web version of this article.)

show that the magma was flowing toward the North, or more precisely toward the NNE when combined with the orientation of elongated bubbles and the scatter of $K_{3}$ axes (Figs. 4a and 8). In addition, the asymmetry of magnetic foliation imbrications across the sill (Fig. 8b) implies an asymmetric flow velocity profile of the magma (Figs. 9b, 13b), which can only be explained by a NNEdirected slip of the hanging wall of the sill. The velocity profile of magma flow in the intrusion is sketched in Fig. 13d with ellipses dip, dip direction, surface and elongation drawn in proportion to the AMS data. In that way, the velocity profile is represented at an arbitrary scale by positioning each ellipse on the $\mathrm{X}$ axis at a distance from the next ellipse proportional to the dip to and the anisotropy of the magnetic fabric. Hence, the less inclined and more elongated are the ellipses, the greater is the velocity difference between two ellipses. This schematic representation corresponds to an asymmetric velocity profile in which the magma flow velocity exceeds the slip velocity of the upper intrusion wall, the two velocity vectors being collinear (case 2 in Correa-Gomes et al. (2001)). This asymmetric magma flow profile is in agreement with a normal slip of the upper intrusion wall and a slip vector plunging toward the NNE.

\subsection{Implication for the role of sill intrusions in volcano flank instability}

Field and AMS data show that the contact sill acted as a low-angle normal fault slipping toward the NNE. This kinematics is consistent with the SSW-NNE extension that occurred at Piton des Neiges from its shield building stage to its recent degenerative history (Chaput et al., 2014b). It should be recalled that the contact sill is the latest of a suite of at least 50 sill intrusions in the sill zone, according to the observed indicators of relative chronology (Fig. 3). Since all the sills have a common orientation and dip, it is likely that the other sills were also sheared in the same direction during their intrusion. It is also important to recall that the debris avalanche is posterior to the contact sill, and eroded the upper part of the sill zone as indicated by the nature of the elements in the basal unit of the breccia. According to this chronology, we propose that the striations at the contact sill surface
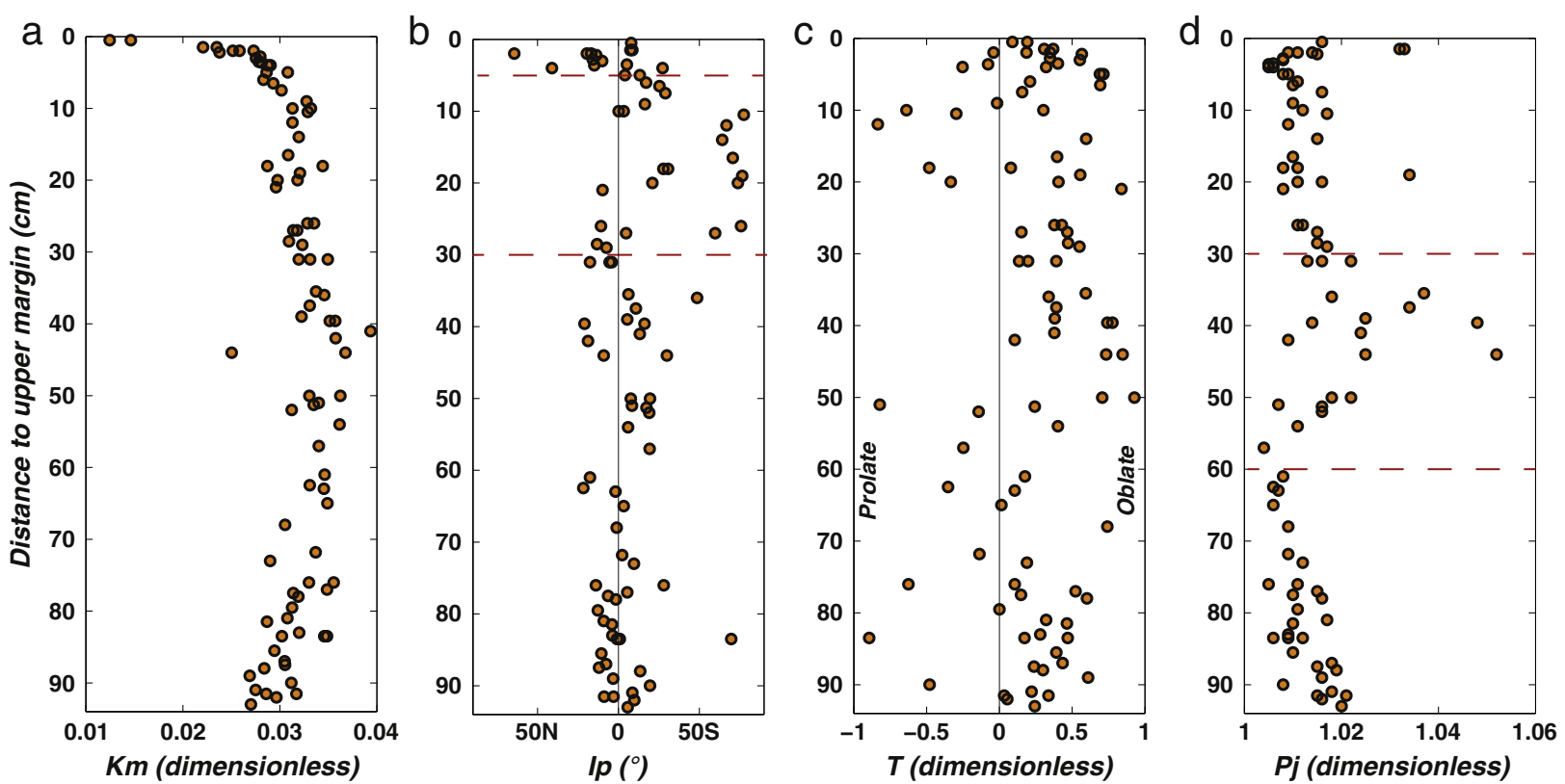

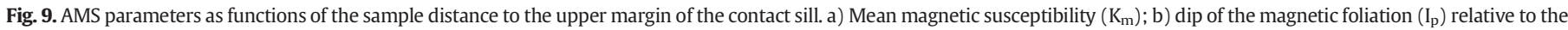

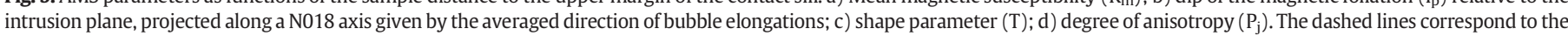
boundaries of domains described in text. 
a

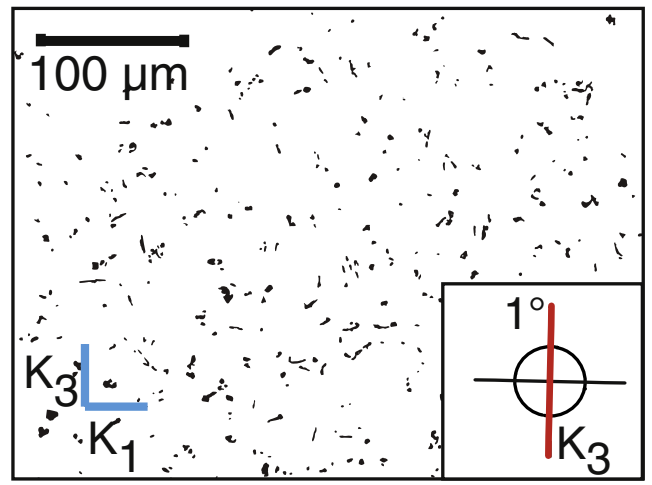

b

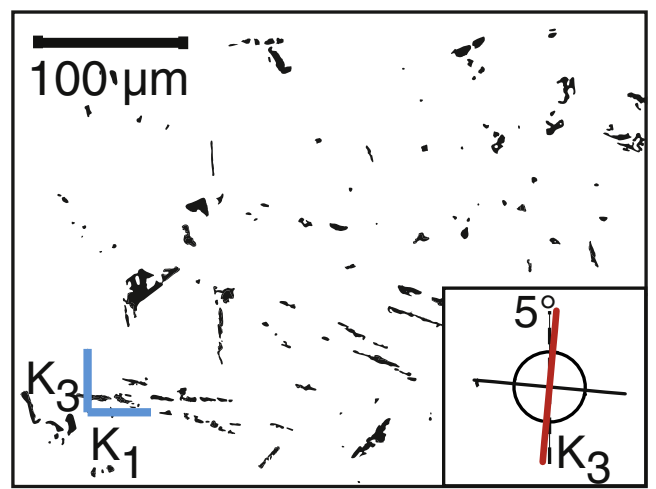

C

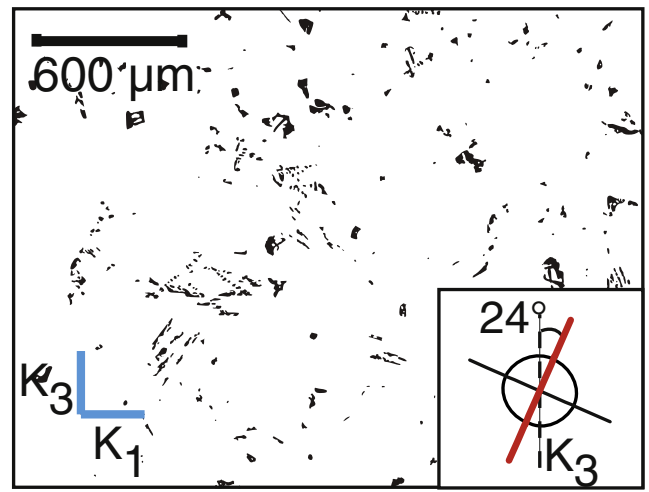

d

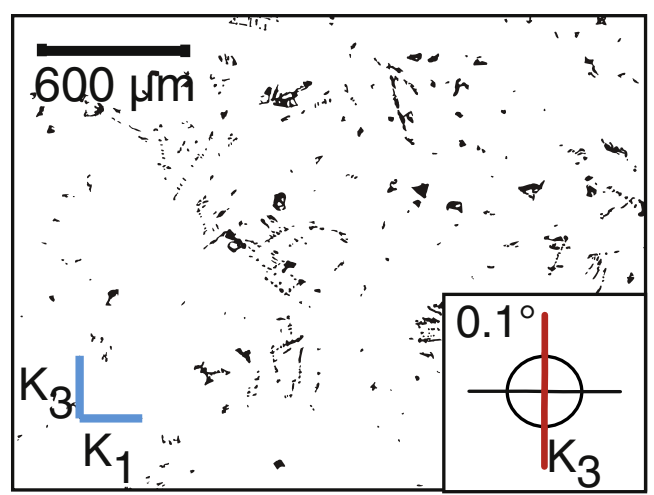

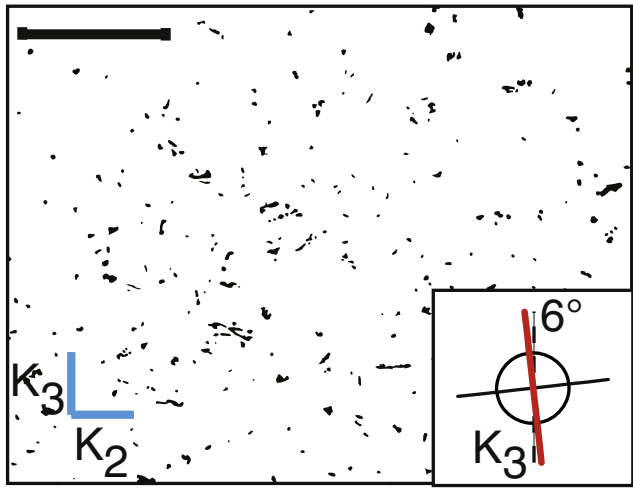
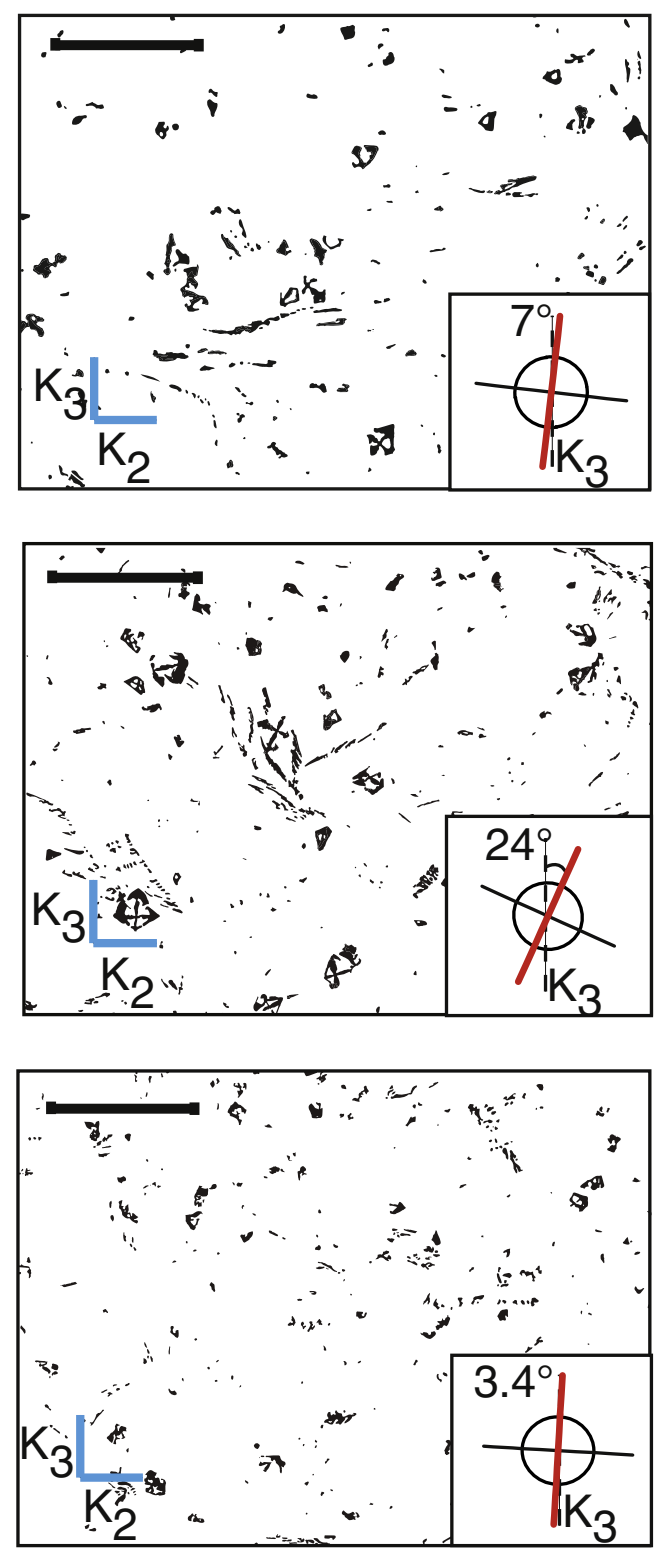

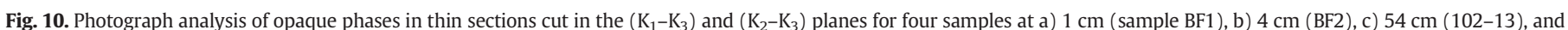

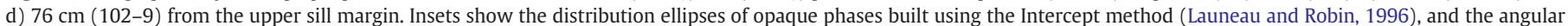
deviation between their short axis (red lines) and $\mathrm{K}_{3}$.

result from the passage of the debris avalanche. Finally, there is a good consistency between the NNE dip direction of the sill zone, the SW$\mathrm{NE}$ or $\mathrm{N018} \pm 25$ direction of magma flow in the sill and the N019 \pm 18 direction of striations (Fig. 4). This suggests that the avalanche runout was driven by the slope of the sill zone, as was the flow of magma in the sills.

Famin and Michon (2010) proposed, without observational evidence, that the injection of seaward-dipping sills could induce a 


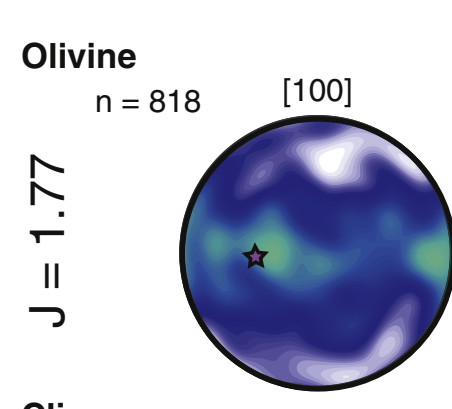

Sample at $1 \mathrm{~cm}$

Clinopyroxene
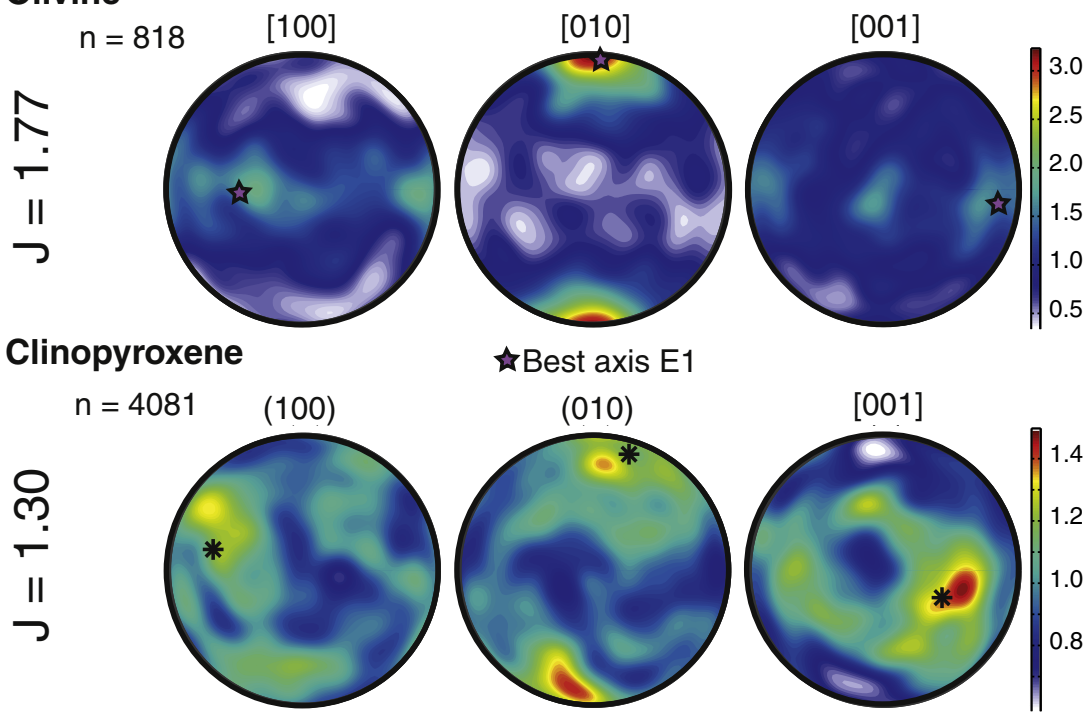

Best axis E1

Plagioclase

(010)
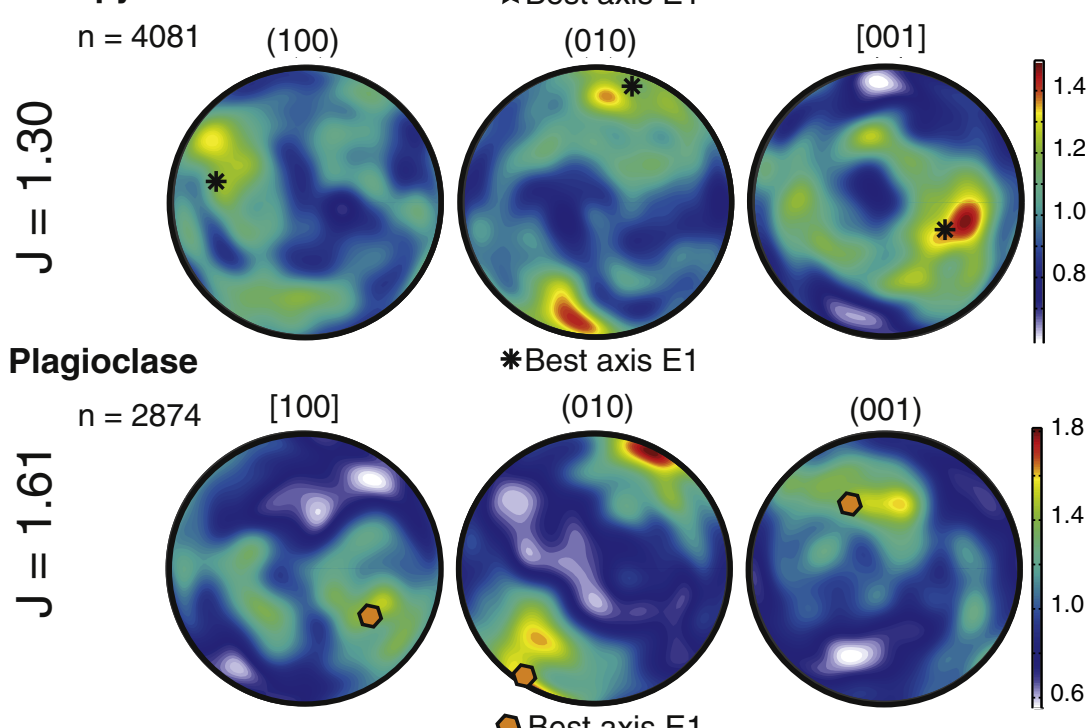

O Best axis E1

\section{Olivine}

Sample at $4 \mathrm{~cm}$

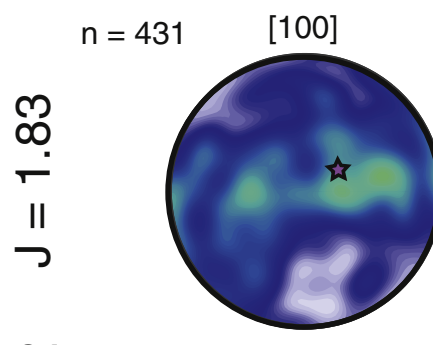

Clinopyroxene

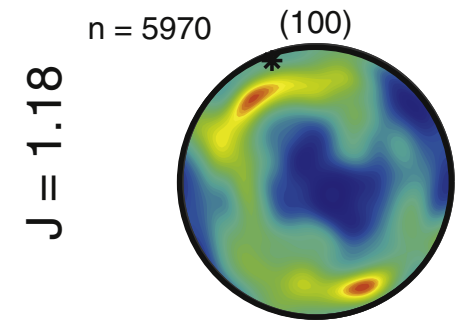

Plagioclase
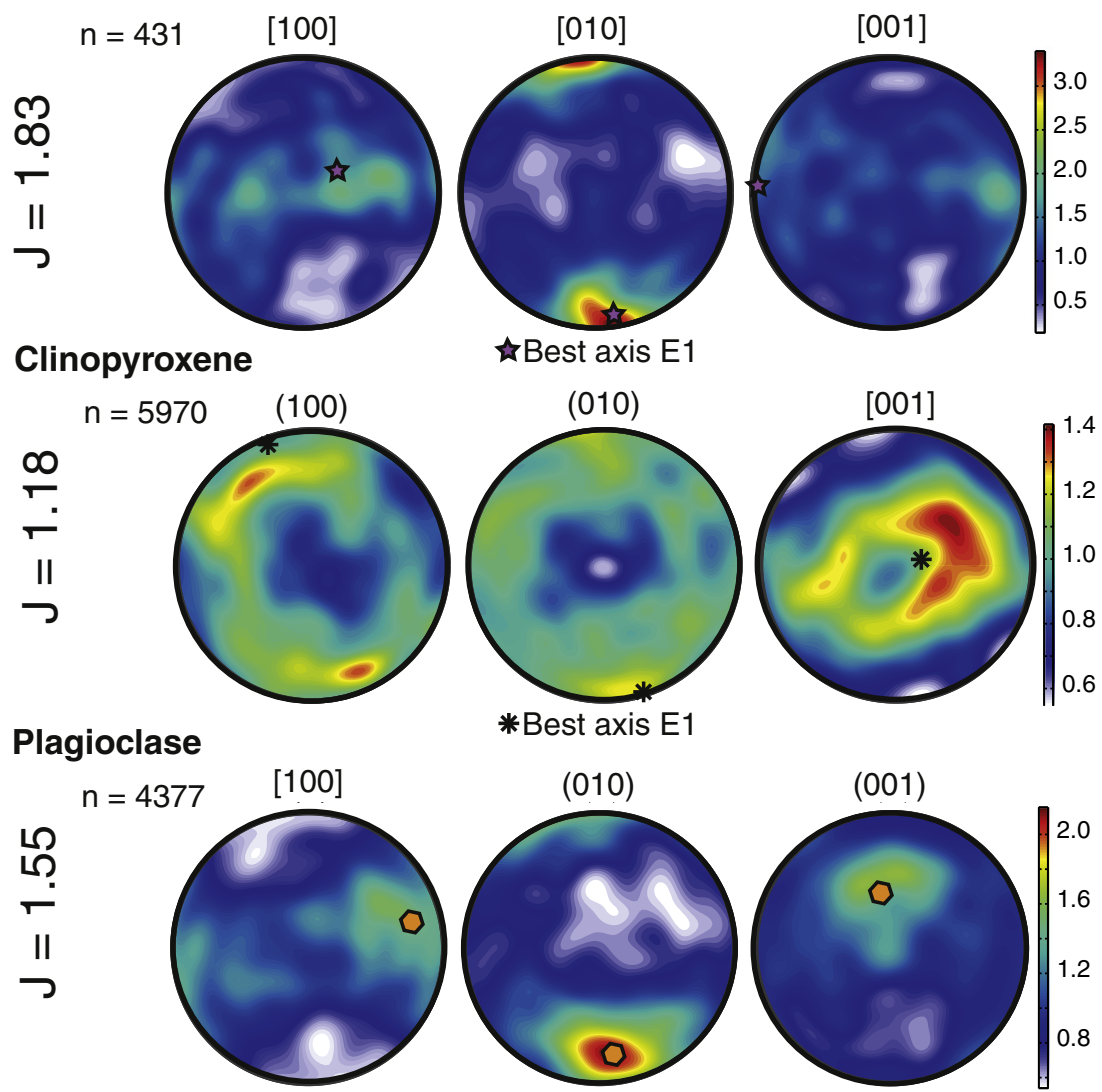

*Best axis E1
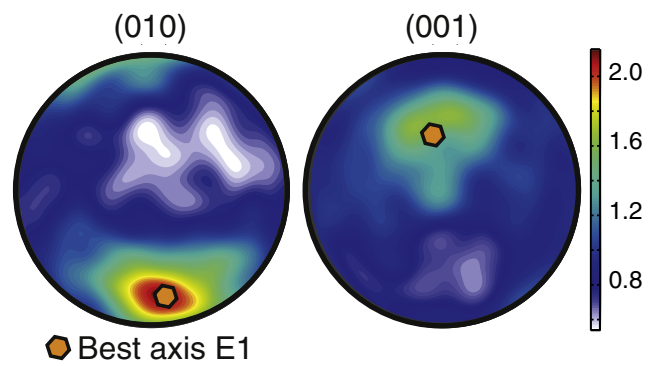


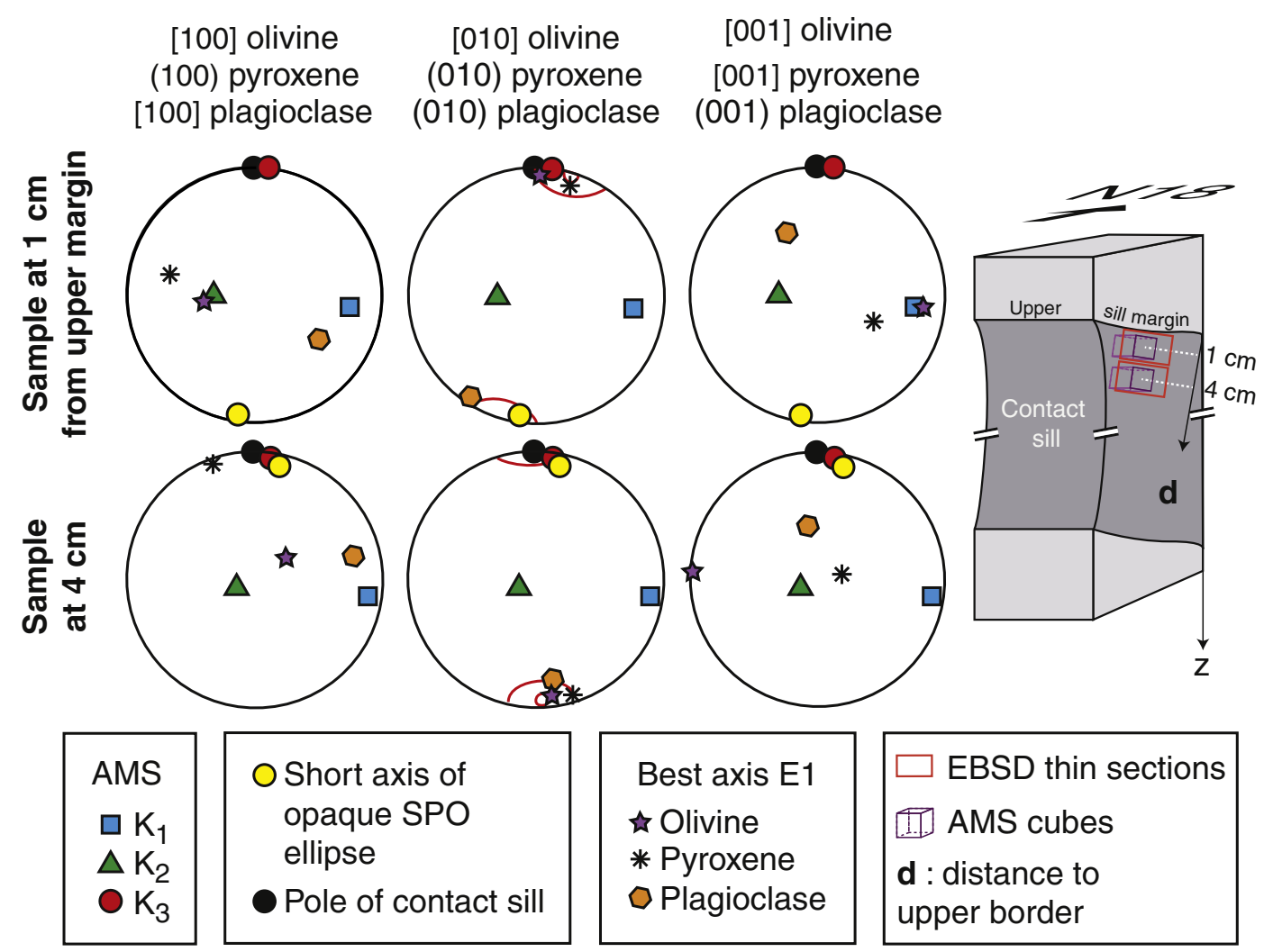

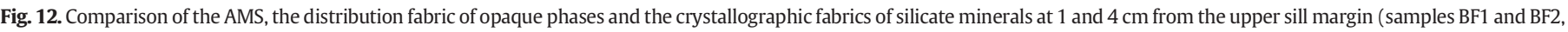

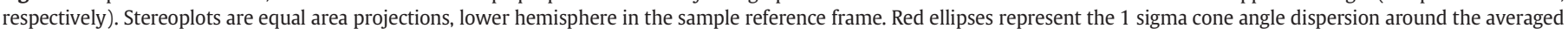

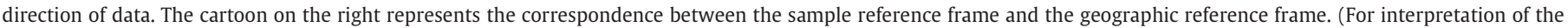
references to color in this figure legend, the reader is referred to the web version of this article.)

cointrusive slip of the volcano flank and may increase its instability. Since then, the role of sheared sill intrusions as a trigger of flank instability has been tested numerically. Using the observed geometry of the Piton des Neiges sill zone, Cayol et al. (2014) computed that the injection of sills in a volcanic edifice undergoing extension would generate an averaged shear displacement of $3.7 \mathrm{~m}$ per sill, or a total lateral displacement of 180-260 $\mathrm{m}$ for the sill zone. In addition, (Chaput et al., 2014a) showed that the injection of a sill could be sufficient to activate a detachment such as the one found at Piton des Neiges. These authors also suggested that the intrusion of a sill in a detachment could explain the $1.4 \mathrm{~m}$ coeruptive lateral flank displacement observed at Piton de la Fournaise during the 2007 eruption.

Our study provides evidence of a slip displacement during sill intrusion in a basaltic edifice, and thus substantiates all these previous models by direct observations. Due to the shear displacement of their hanging wall, sill intrusions increased the instability of Piton des Neiges' flank. This incremental instability possibly explains the massive destabilization with slip toward the NNE, i.e. toward the dip direction of the sill zone and toward the direction of magma propagation in the contact sill. Applying this conclusion to Piton de la Fournaise, repeated coeruptive flank displacements like those observed in 2007 eventually trigger a large flank destabilization as it did on Piton des Neiges.

Sill intrusions have been observed on other volcanic islands worldwide, such as Oahu in Hawaii (Ryan et al., 1983), La Palma and La Gomera in the Canaries (Staudigel et al., 1986; Fernandez et al., 2002; Ancochea et al., 2008), Saint-Vincent in the Antilles Arc (Ancochea et al., 2010), or inferred from radar interferometry at Fernandina in the Galapagos (Jónsson et al., 1999; Bagnardi et al., 2013). Our study suggests that such sill intrusions may be responsible for some of the past destabilizations documented on these oceanic islands, and perhaps for some of the lateral displacements recorded during present-day eruptions. These displacements might evolve into future destabilizations on active volcanoes.

\section{Conclusion}

Our study of the sill zone of Piton des Neiges reveals that a major NNE-running debris avalanche partly eroded this sheeted intrusion complex. The most recent of the remaining sills, identified by markers of relative intrusion chronology, makes the contact between the debris avalanche deposit and the sill zone. The AMS study carried out across this contact sill reveals a strongly asymmetric magnetic fabric, suggesting that 1) the magma in the sill flowed toward the NNE, and 2) that the sill hanging wall slipped in the same direction during magma injection. This result shows that at least one of the sills generated a shear displacement of the hanging wall of the sill zone, and thus a seaward displacement of the volcano flank. Because all the sills in the complex have the same dip and dip direction, it is likely that seaward displacements occurred repeatedly during the history of the volcano. In view of the massive destabilization that occurred subsequently, we conclude that repeated sill injections may have acted as a factor of incremental instability at Piton des Neiges. The same incremental instability by sill 

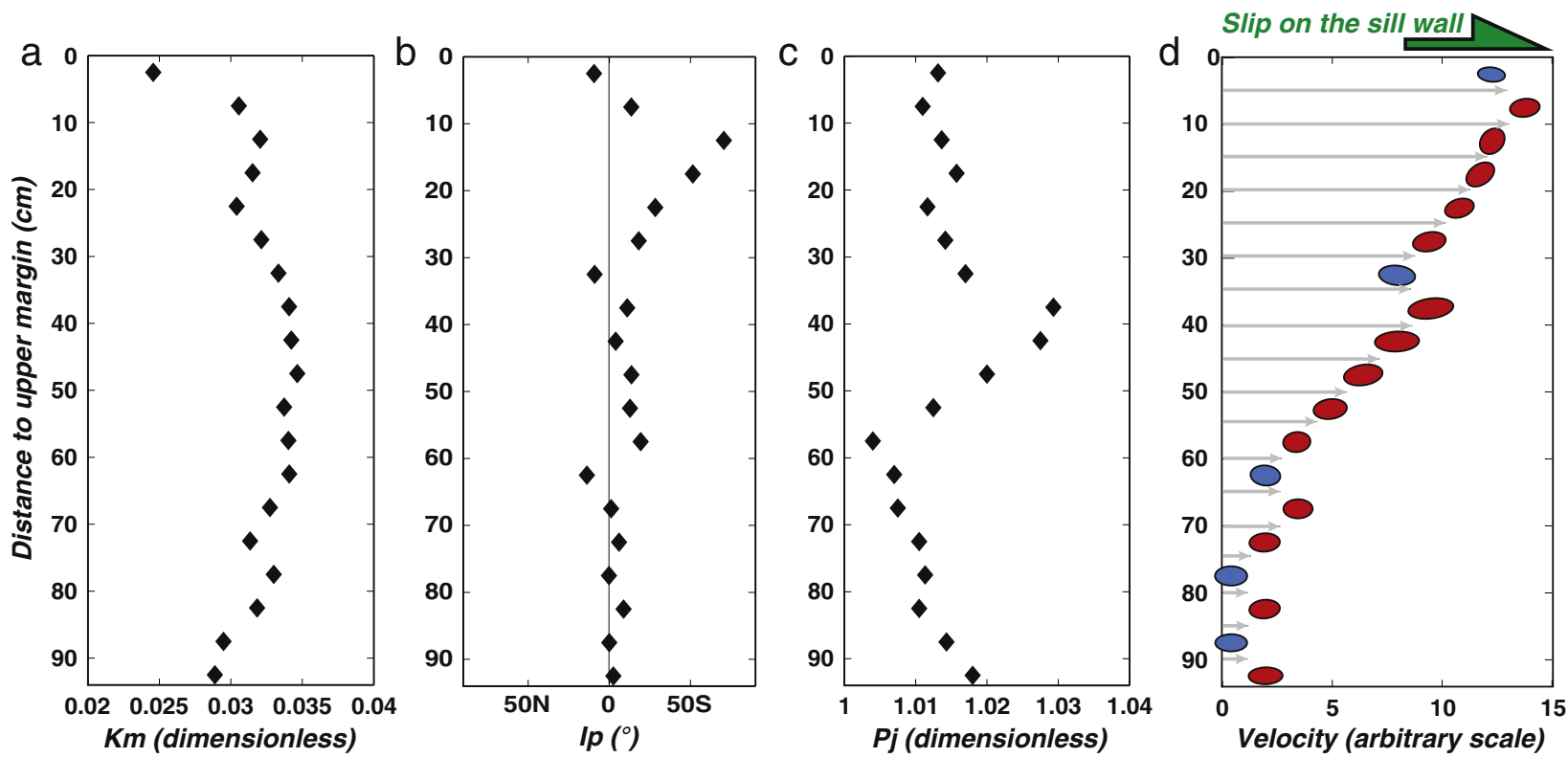

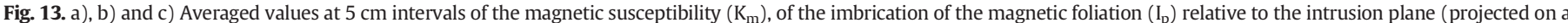

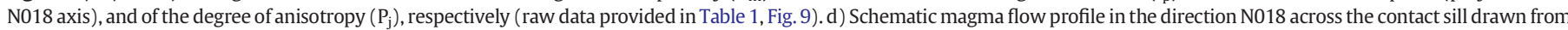

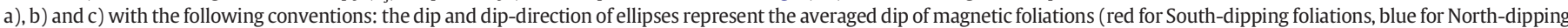

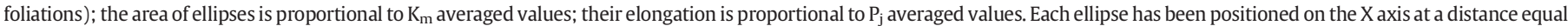
to $\operatorname{sign}\left(I_{p}\right) \cdot \cos \left(I_{p}\right) \times P_{j}$ from the next ellipse.

intrusions is proposed to currently occur at Piton de la Fournaise, the active volcano of La Réunion Island, which may also end up into a destabilization in the future.

\section{Acknowledgments}

We thank Valérie Cayol for providing the idea of searching evidence for sheared sills in the AMS fabric, and Guilhem Barruol for his help in the AMS sampling. Jean-Luc Schneider is thanked for his observation that the breccia is posterior to the sills. We are also grateful for the helpful reviews provided by Stephen S. Harlan and an anonymous reviewer. This research was funded by grants from INSU-CNRS ("Sill'nslip" and "Runrise" projects), from the Fond Social Européen, and from the Conseil Régional de La Réunion. This is IPGP contribution 3714.

\section{References}

Akkoyun, M., Majesté, J.C., Bascou, J., 2013. Using the anisotropy of magnetic susceptibility to infer flow induced orientation of anisotropic particles: feasibility and sensitivity. Rheol. Acta 52, 49-57.

Ancochea, E., Brandle, J.L., Huertas, M.J., Hernán, F., Herrera, R., 2008. Dike-swarms, key to the reconstruction of major volcanic edifices: the basic dikes of La Gomera (Canary Islands). J. Volcanol. Geotherm. Res. 173, 207-216. http://dx.doi.org/10.1016/j. jvolgeores.2008.01.020.

Ancochea, E., Huertas, M.J., Hernán, F., Brändle, J.L., 2010. Volcanic evolution of São Vicente, Cape Verde Islands: the Praia Grande landslide. J. Volcanol. Geotherm. Res. 198, 143-157. http://dx.doi.org/10.1016/j.jvolgeores.2010.08.016.

Arbaret, L., Diot, H., Bouchez, J.-L., 1996. Shape fabrics of particles in low concentration suspensions: 2D analogue experiments and application to tiling in magma. J. Struct. Geol. 18, 941-950. http://dx.doi.org/10.1016/0191-8141(96)00011-9.

Arbaret, L., Fernandez, A., Ježek, J., Ildefonse, B., Launeau, P., Diot, H., 2000. Analogue and numerical modelling of shape fabrics: application to strain and flow determination in magmas. Geol. Soc. Am. Spec. Pap. 350, 97-109. http://dx.doi.org/10.1130/0-81372350-7.97.

Bachèlery, P., Robineau, B., Courteaud, M., Savin, C., 2003. Avalanches de débris sur le flanc occidental du volcan-bouclier Piton des Neiges (Réunion). Bull. Soc. Geol. Fr. 174, $125-140$.

Bachmann, F., Hielscher, R., Schaeben, H., 2010. Texture analysis with MTEX-free and open source software toolbox. Solid State Phenom. 160, 63-68. http://dx.doi.org/10. 4028/http://www.scientific.net/SSP.160.63.
Bagnardi, M., Amelung, F., Poland, M.P., 2013. A new model for the growth of basaltic shields based on deformation of Fernandina volcano, Galápagos Islands. Earth Planet. Sci. Lett. 377-378, 358-366. http://dx.doi.org/10.1016/j.epsl.2013.07.016.

Bascou, J., Camps, P., Marie Dautria, J., 2005. Magnetic versus crystallographic fabrics in a basaltic lava flow. J. Volcanol. Geotherm. Res. 145, 119-135. http://dx.doi.org/10. 1016/j.jvolgeores.2005.01.007.

Boiron, T., Bascou, J., Camps, P., Ferre, E.C., Maurice, C., Guy, B., Gerbe, M.C., Launeau, P., 2013. Internal structure of basalt flows: insights from magnetic and crystallographic fabrics of the La Palisse volcanics, French Massif Central. Geophys. J. Int. 193, 585-602. http://dx.doi.org/10.1093/gji/ggs115.

Borgia, A., 1994. Dynamic basis of volcanic spreading. J. Geophys. Res. 99, 17,791-717,804

Bret, L., Fevre, Y., Join, J.-L., Robineau, B., Bachelery, P., 2003. Deposits related to degradation processes on Piton des Neiges Volcano (Reunion Island): overview and geological hazard. J. Volcanol. Geotherm. Res. 123, 25-41. http://dx.doi.org/10.1016/s03770273(03)00026-X.

Callot, J.-P., Geoffroy, L., Aubourg, C., Pozzi, J.P., Mege, D., 2001. Magma fow directions of shallow dykes from the East Greenland volcanic margin inferred from magnetic fabric studies. Tectonophysics 335, 313-332. http://dx.doi.org/10 1016/S0040-1951(01)00060-9.

Cañón-Tapia, E., 2004. Anisotropy of magnetic susceptibility of lava flows and dykes: a historical account. Geol. Soc. Lond. 238, 205-225. http://dx.doi.org/10.1144/GSL.SP. 2004.238.01.14.

Cañón-Tapia, E., Pinkerton, H., 2000. The anisotropy of magnetic susceptibility of lava flows: an experimental approach. J. Volcanol. Geotherm. Res. 98, 219-233. http:// dx.doi.org/10.1016/S0377-0273(99)00155-9.

Cayol, V., Catry, T., Michon, L., Chaput, M., Famin, V., Bodart, O., Froger, J.-L., Romagnoli, C 2014. Sheared sheet intrusions as mechanism for lateral flank displacement on basaltic volcanoes: applications to Réunion Island volcanoes. J. Geophys. Res. Solid Earth 119, 7607-7635. http://dx.doi.org/10.1002/2014JB011139.

Chadima, M., Hrouda, F., 2009. Cureval 8.0: Thermomagnetic Curve Browser for Windows. Agico, Inc.

Chadima, M., Jelinek, V., 2008. Anisoft 4.2 - anisotropy data browser. Contrib. Geophys Geodesy 38, 41.

Chaput, M., Famin, V., Michon, L., 2014b. Deformation of basaltic shield volcanoes under cointrusive stress permutations. J. Geophys. Res. Solid Earth 119, 274-301. http:// dx.doi.org/10.1002/2013JB01062.

Chaput, M., Pinel, V., Famin, V., Michon, L., Froger, J.L., 2014a. Cointrusive shear displacement by sill intrusion in a detachment: a numerical approach. Geophys. Res. Lett. 41, 1937-1943. http://dx.doi.org/10.1002/2013GL058813.

Chevallier, L., Vatin-Perignon, N., 1982. Volcano-structural evolution of piton des Neiges, Reunion Island, Indian Ocean. Bull. Volcanol. 45-4, 285-298.

Clague, D.A., Delinguer, R.P., 1994. Role of olivine cumulates in destabilizing the flanks of Hawaiian volcanoes. Bull. Volcanol. 56, 425-435. http://dx.doi.org/10.1007/BF00302824.

Clark, D.A., 1997. Magnetic petrophysics and petrology: aids to geological interpretation of magnetic surveys. J. Aust. Geol. Geophys. 17, 83-103.

Correa-Gomes, L.C., Souza Filho, C.R., Martins, C.J.F.N., Oliveira, E.P., 2001. Development of symmetrical and asymmetrical fabrics in sheet-like igneous bodies: the role of magma 
flow and wall-rock displacements in theoretical and natural cases. Journal of structura geology 23, 1415-1428. http://dx.doi.org/10.1016/S0191-8141(01)00007-4.

Deniel, C., Kieffer, G., Lecointre, J., 1992. New 230Th-238 U and 14C age determinations from piton des Neiges volcano, Reunion-a revised chronology for the differentiated series. J. Volcanol. Geotherm. Res. 51, 253-267. http://dx.doi.org/10.1016/0377 0273(92)90126-X

Dieterich, J., 1988. Growth and persistence of Hawaiian volcanic rift zones. J. Geophys. Res. Solid Earth (1978-2012) 93, 4258-4270.

Dragoni, M., Lanza, R., Tallarico, A., 1997. Magnetic anisotropy produced by magma flow: theoretical model and experimental data from Ferrar dolerite sills (Antarctica). Geophys. J. Int. 128, 230-240. http://dx.doi.org/10.1111/j.1365-246X.1997. tb04083.x.

Ellwood, B.B., 1978. Flow and emplacement direction determined for selected basaltic bodies using magnetic susceptibility anisotropy measurements. Earth Planet. Sci. Lett. 41, 254-264. http://dx.doi.org/10.1016/0012-821X(78)90182-6.

Elsworth, D., Day, S.J., 1999. Flank collapse triggered by intrusion: the canarian and Cape Verde archipelagoes. J. Volcanol. Geotherm. Res. 94, 323-340. http://dx.doi.org/10. 1016/S0377-0273(99)00110-9.

Famin, V., Michon, L., 2010. Volcano destabilization by magma injections in a detachment Geology 38, 219-222. http://dx.doi.org/10.1130/g30717.1.

Fernandez, C., de la Nuez, J., Casillas, R., Navarro, G., 2002. Stress fields associated with the growth of a large shield volcano (La Palma, Canary Islands). Tectonics 21. http://dx. doi.org/10.1029/2000TC900038.

Froger, J., Famin, V., Cayol, V., Augier, A., Michon, L., Lénat, J.-F., 2015. Time-dependant displacements during and after the april 2007 eruption of Piton de la Fournaise, revealed by interferometric data. J. Volcanol. Geotherm. Res. 296, 55-68. http://dx.doi.org/10. 1016/j.jvolgeores.2015.02.014.

Gailler, L.-S., Lénat, J.-F., 2010. Three-dimensional structure of the submarine flanks of La Réunion inferred from geophysical data. J. Geophys. Res. Solid Earth (1978-2012) 115. http://dx.doi.org/10.1029/2009jb007193.

Geoffroy, L., Aubourg, C., Callot, J.-P., Barrat, J.-A., 2007. Mechanisms of crustal growth in large igneous provinces: the North Atlantic province as a case study. Geol. Soc. Am. Spec. Pap. 430, 747-774. http://dx.doi.org/10.1130/2007.2430(34).

Geoffroy, L., Callot, J.-P., Aubourg, L., Moreira, M., 2002. Magnetic and plagioclase linear fabric discrepancy in dykes: a new way to define the flow vector using magnetic foliation. Terra Nova 14, 183-190. http://dx.doi.org/10.1046/j.1365-3121.2002.00412.x.

Gillot, P.-Y., Nativel, P., 1982. K-Ar chronology of the ultimate activity of the Piton des Neiges volcano, Reunion Island, Indian Ocean. J. Volcanol. Geotherm. Res. 13, 131-146. http://dx.doi.org/10.1016/0377-0273(82)90024-5.

Graham, J.W., 1954. Magnetic susceptibility anisotropy, an unexploited petrofabric element. Geol. Soc. Am. Bull. 65, 1257-1258.

Hargraves, R.B., Johnson, D., Chan, C.Y., 1991. Distribution anisotropy: the cause of AMS in igneous rocks? Geophys. Res. Lett. 18, 2193-2196.

Hastie, W.W., Watkeys, M.K., Aubourg, C., 2011. Significance of magnetic and petrofabric in Karoo-feeder dykes, Northern Lebombo. Tectonophysics 513, 96-111. http://dx. doi.org/10.1016/j.tecto.2011.10.008.

Hielscher, R., Schaeben, H., 2008. A novel pole figure inversion method: specification of the MTEX algorithm. J. Appl. Crystallogr. 41, 1024-1037.

Hrouda, F., Buriánek, D., Krejčí, O., Chadima, M., 2015. Magnetic fabric and petrology of Miocene sub-volcanic sills and dykes emplaced into the SW Flysch Belt of the West Carpathians (S Moravia, Czech Republic) and their volcanological and tectonic implications. J. Volcanol. Geotherm. Res. 290, 23-38. http://dx.doi.org/10.1016/j. jvolgeores.2014.12.001.

Ildefonse, B., Arbaret, L., Diot, H., 1997. Rigid Particles in Simple Shear Flow: Is Their Preferred Orientation Periodic or Steady-State? Granite: from Segregation of Melt to Emplacement Fabrics. pp. 177-185 http://dx.doi.org/10.1007/978-94-017-1717-5_11.

Ildefonse, B. Launeau, P., Bouchez, J-L, Fernandez, A., 1992. Effect of mechanical interactions on the development of shape preferred orientations: a two-dimensional experimental approach. J. Struct. Geol. 14, 73-83. http://dx.doi.org/10.1016/01918141(92)90146-N

Iverson, R.M., 1995. Can magma-injection and groundwater forces cause massive landslides on Hawaiian volcanoes? J. Volcanol. Geotherm. Res. 66, 295-308. http://dx. doi.org/10.1016/0377-0273(94)00064-N.

Jelinek, F., Kropàcek, V., 1978. Statistical processing of magnetic susceptibility measured in groups of specimens. Stud. Geophys. Geod. 22, 50-62.

Jónsson, S., Zebker, H., Cervelli, P., Segall, P., Garbeil, H., Mouginis-Mark, P., Rowland, S. 1999. A shallow-dipping dike fed the 1995 flank eruption at Fernandina volcano, Galápagos, observed by satellite radar interferometry. Geophys. Res. Lett. 26 1077-1080. http://dx.doi.org/10.1029/1999gl900108.

Khan, M.A., 1962. The anisotropy of magnetic susceptibility of some igneous and metamorphic rocks. Contrib. Geophys. Geodesy 38.

Kluska, J.M., 1997. Evolution Magmatique et Morphostructurale Du Piton Des Neiges Au Cours Des Derniers 500000 Ans. Orsay Paris XI university, p. 229

Knight, M.D., Walker, G.P.L., 1988. Magma flow directions in dikes of the Koolau Complex Oahu, determined from magnetic fabric studies. J. Geophys. Res. 93, 4301-4319. http://dx.doi.org/10.1029/JB093iB05p04301.

Launeau, P., Robin, P.-Y.F., 1996. Fabric analysis using the intercept method Tectonophysics 267, 91-119. http://dx.doi.org/10.1016/S0040-1951(96)00091-1.
Launeau, P., Archanjo, C.J., Picard, D., Arbaret, L., Robin, P.-Y., 2010. Two- and threedimensional shape fabric analysis by the intercept method in grey levels. Tectonophysics 492, 230-239. http://dx.doi.org/10.1016/j.tecto.2010.06.005.

Launeau, P., Bouchez, J.-L., Benn, K., 1990. Shape preferred orientation of object populations: automatic analysis of digitized images. Tectonophysics 180, 201-211. http:// dx.doi.org/10.1016/0040-1951(90)90308-U.

Lundgren, P., 2004. Gravity and magma induced spreading of Mount Etna volcano revealed by satellite radar interferometry. Geophys. Res. Lett. 31. http://dx.doi.org/ 10.1029/2003gl018736

Mainprice, D., Bachmann, F., Hielscher, R., Schaeben, H., 2014. Descriptive tools for the analysis of texture projects with large datasets using MTEX: strength, symmetry and components. Geol. Soc. Lond. Spec. Publ. 409. http://dx.doi.org/10. $1144 /$ SP409.8

McGuire, W.J., 1996. Volcano instability: a review of contemporary themes. Geol. Soc. Lond., Spec. Publ. 110, 1-23. http://dx.doi.org/10.1144/gsl.sp.1996.110.01.01.

Montgomery-Brown, E.K., Sinnett, D.K., Larson, K.M., Poland, M.P., Segall, P., Miklius, A., 2011. Spatiotemporal evolution of dike opening and décollement slip at Kīlauea Volcano, Hawaii. J. Geophys. Res. 116 10.1029/2010jb007762.

Moore, J.G., Clague, D.A., Holcomb, R.T., Lipman, P.W., Normark, W.R., Torresan, M.E., 1989. Prodigious submarine landslides on the Hawaiiin Ridge. J. Geophys. Res. Solid Earth (1978-2012) 94, 465-484. http://dx.doi.org/10.1029/JB094iB12p17465.

Moreira, M.A., Geoffroy, L., Pozzi, J.P., 2014. Magma flow pattern in dykes of the Azores revealed by anisotropy of magnetic susceptibility. J. Geophys. Res. Solid Earth 120, 662-690. http://dx.doi.org/10.1002/2014JB010982.

Oehler, J.-F., Labazuy, P., Lénat, J.-F., 2004. Recurrence of major flank landslides during the last 2-Ma-history of Reunion Island. Bull. Volcanol. 66, 585-598. http://dx.doi.org/10. 1007/s00445-004-0341-2.

Oehler, J.-F., Lénat, J.-F., Labazuy, P., 2007. Growth and collapse of the Reunion Island volcanoes. Bull. Volcanol. 70, 717-742. http://dx doi.org/10.1007/s00445-007-0163-0.

Philpotts, A., Philpotts, D., 2007. Upward and downward flow in a camptonite dike as recorded by deformed vesicles and the anisotropy of magnetic susceptibility (AMS). J. Volcanol. Geotherm. Res. 161, 81-94. http://dx.doi.org/10.1016/j.jvolgeores.2006. 11.006

Quidelleur, X., Holt, J.W., Salvany, T., Bouquerel, H., 2010. New K-Ar ages from La Montagne massif, Réunion Island (Indian Ocean), supporting two geomagnetic events in the time period 2.2-2.0 Ma. Geophys. J. Int. 182, 699-710. http://dx.doi. org/10.1111/j.1365-246X.2010.04651.X.

Rochette, P., Jackson, M., Aubourg, C., 1992. Rock magnetism and the interpretation of an anisotropy of magnetic susceptibility. Rev. Geophys. 30, 209-226. http://dx.doi.org/ 10.1029/92RG00733.

Ryan, M., Blevins, J.Y.K., Okanura, A.T., Koyanagi, R.Y., 1983. Magma reservoir subsidence mechanics: theoretical summary and application to Kilauea volcano, Hawaii. J. Geophys. Res. Solid Earth (1978-2012) 88, 4147-4181. http://dx.doi.org/10.1029/ JB088iB05p04147.

Salvany, T., Lahitte, P., Nativel, P., Gillot, P.-Y., 2012. Geomorphic evolution of the Piton des Neiges volcano (Réunion Island, Indian Ocean): competition between volcanic construction and erosion since 1.4 Ma. Geomorphology 136, 132-147. http://dx.doi. org/10.1016/j.geomorph.2011.06.009.

Satsukawa, T., Ildefonse, B., Mainprice, D., Morales, L., Michibayashi, K., Barou, F., 2013. A database of plagioclase crystal preferred orientations (CPO) and microstructures \&ndash; implications for CPO origin, strength, symmetry and seismic anisotropy in gabbroic rocks. Solid Earth 42, 511-542. http://dx.doi.org/10.5194/se-4-511-2013.

Schmidt, N.-H., Olesen, N., 1989. Computer-aided determination of crystal-lattice orientation from electron-channeling patterns inthe SEM. Can. Mineral. 27, 15-22.

Siebert, L., 1984. Large volcanic debris avalanches: characteristics of source areas deposits, and associated eruptions. J. Volcanol. Geotherm. Res. 22, 163-197.

Stacey, F.D., 1960. Magnetic anisotropy of igneous rocks. J. Geophys. Res. 65, 2429-2442. http://dx.doi.org/10.1029/JZ065i008p02429.

Staudigel, H., Feraud, G., Giannerini, G., 1986. The history of intrusive activity on the island of La Palma (Canary Islands). J. Volcanol. Geotherm. Res. 27, 299-322. http://dx.doi. org/10.1016/0377-0273(86)90018-1.

Swanson, D., Duffield, W.A., Fiske, R.S., 1976. In: off. u.g.p. (Ed.), Displacement of the South Flank of Kilauea Volcano: the Result of Forceful Intrusion of Magma Into Rift Zones.

Tauxe, L., Gee, J.S., Staudigel, H., 1998. Flow directions in dikes from anisotropy of magnetic susceptibility data: the bootstrap way. J. Geophys. Res. Solid Earth (1978-2012) 103, 17,775-717,790. http://dx.doi.org/10.1029/98jb01077.

Voight, B., Glicken, H., Janda, R.J., Douglass, P.M., Lipman, P.W., Mullineaux, D.R., 1981. Catastrophic rockslide avalanche of May 18 [Mount St. Helens]. In: Lipman, P.W., Mullineaux, D.R. (Eds.), The 1980 Eruptions of Mount St. Helens. US Geol. Surv. Prof. Pap., pp. 347-377 Washington.

Walter, T.R., Acocella, V., Neri, M., Amelung, F., 2005. Feedback processes between magmatic events and flank movement at Mount Etna (Italy) during the 2002-2003 eruption. J. Geophys. Res. Solid Earth 110, 1-12. http://dx.doi.org/10.1029/2005jb003688.

Zhang, S., Cañón-Tapia, E., Walderhaug, H.J., 2011. Magnetic fabric and its significance in the sills and lava flows from Taimyr fold-belt, Arctic Siberia. Tectonophysics 505, 68-85. http://dx.doi.org/10.1016/j.tecto.2011.04.004. 